\title{
Corporate Governance for Responsible Innovation: Approaches to Corporate Governance and Their Implications for Sustainable Development
}

\author{
Scherer, Andreas ; Voegtlin, Christian
}

DOI: https://doi.org/10.5465/amp.2017.0175

Posted at the Zurich Open Repository and Archive, University of Zurich ZORA URL: https://doi.org/10.5167/uzh-173227

Journal Article

Accepted Version

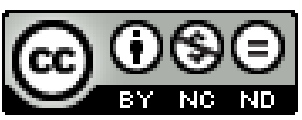

The following work is licensed under a Creative Commons: Attribution-NonCommercial-NoDerivatives 4.0 International (CC BY-NC-ND 4.0) License.

Originally published at:

Scherer, Andreas; Voegtlin, Christian (2020). Corporate Governance for Responsible Innovation: Approaches to Corporate Governance and Their Implications for Sustainable Development. The Academy of Management Perspectives, 34(2):182-208.

DOI: https://doi.org/10.5465/amp.2017.0175 


\title{
CORPORATE GOVERNANCE FOR RESPONSIBLE INNOVATION:
}

\section{APPROACHES TO CORPORATE GOVERNANCE AND THEIR IMPLICATIONS FOR SUSTAINABLE DEVELOPMENT}

\author{
ANDREAS GEORG SCHERER \\ University of Zurich \\ andreas.scherer@uzh.ch \\ CHRISTIAN VOEGTLIN \\ Audencia Business School \\ cvogtlin@audencia.com
}

Unedited version of a paper published in Academy of Management Perspectives, 34(2), 182-208, 2020, DOI https://doi.org/10.5465/amp.2017.0175.

For private use only. For correct citations and quotations please see the original publication in the Academy of Management Perspectives.

Acknowledgments: The authors thank AMP editors Ruth Aguilera, Igor Filatotchev, and Mike Wright for their helpful comments and kind support. We were very saddened to hear of the passing of Mike Wright. [AU: We feel like we should acknowledge Mike's passing. If you would like to word this differently or add anything, feel free.] We have greatly benefited from discussions at the 2017 AOM symposium "From Governance of Innovation to Innovations in Governance" and thank all participants. We thank Cristina Neesham and Vincent Blok for their valuable input concerning the COVID-19 pandemic case. We thank Ann Nelson and Lynn Selhat for English language editing. The authors acknowledge the support by the Swiss National Science Foundation for the project "When Individuals Become Social Innovators: Investigating Social Innovative Behavior and Its Individual and Contextual Preconditions" (project no. 100010_165699/1). 


\begin{abstract}
The grand challenges that humanity faces_- poverty, inequality, hunger, conflict, climate change, deforestation, pandemic, among others - hinder the progress of sustainable development. These issues can be addressed only by fundamental changes in behavior, as well as in the modes and processes of production and of business more generally. In this paper we will develop the concept of responsible innovation and discuss the potential and limitations of various models of corporate governance with regard to responsible innovation. Our analysis imports from the political sciences theoretical and empirical insights into how alternative forms of participative and reflexive governance can help address the social and environmental challenges that society faces. The paper thereby offers examples of innovative corporate governance that can help to generate innovations that do good and avoid harm. We also illustrate the governance challenges and the role of responsible innovation in the advent of the new coronavirus pandemic (COVID-19).
\end{abstract}

Keywords: business ethics, corporate governance, corporate social responsibility, COVID19, deliberation, democracy, grand challenges, Habermas, pandemic, reflexive governance, sustainable development 
Humanity is facing a number of grand challenges threatening a sustainable future for our planet (Ferraro, Etzion, \& Gehman, 2015; George, Howard-Grenville, Joshi, \& Tihanyi, 2016). Currently there seem to be no adequate responses to deal with these major challenges - poverty, inequality, hunger, access to water, violent conflicts, deforestation, ocean acidification, climate change, biodiversity loss, and infectious diseases or pandemicsall of which appear to be escalating (Griggs et al., 2013; Whiteman, Walker, \& Perego, 2013). Worryingly, some experts claim that certain critical thresholds have already been crossed and the earth's life-support system is in peril (Rockström et al., 2009). In view of these challenges, there are urgent calls for concerted efforts to reduce the concomitant repercussions on world peace, health, stability, and prosperity (George et al., 2016).

The United Nations (UN), the European Union (EU), international organizations, and individual countries are seeking ways to deal with these grand challenges (Waddock, 2008). Many of these initiatives - a prominent example is the United Nations Global Compact (UNGC) - aim to involve businesses as active participants and to encourage collaboration of businesses with public and civil society actors to foster sustainable development (Rasche, Waddock, \& MacIntosh, 2013; Voegtlin \& Pless, 2014). However, despite the frequent pleas for corporate contributions to sustainable development (Marcus \& Fremeth, 2009) and the acknowledgment of increased corporate responsibilities (Matten \& Crane, 2005; Scherer \& Palazzo, 2007), the role of business firms is still ambivalent (Scherer, Palazzo, \& Matten, 2009).

On one hand, businesses do take responsibility; they provide sustainable products and services, engage in corporate social responsibility (CSR) or sustainability initiatives and produce public goods (Kaul, Conceicao, Le Goulven, \& Mendoza, 2003; Matten \& Crane, 2005). On the other hand, their contributions are often more symbolic than substantial (Laufer, 2003; Sethi \& Schepers, 2013). Even worse, business firms are frequently pivotal actors in contributing to social misery and environmental disasters (Banerjee, 2007; Fleming 
\& Jones, 2013; with regard to recent scandals see Eberl, Geiger, \& Aßländer, 2015; Rhodes, 2016; Schembera \& Scherer, 2017). This suggests that there is something wrong in the internal decision-making and incentive structures of businesses - that is, in their corporate governance structures and in the way they implement these structures to meet societal challenges (see, e.g., Bazerman \& Tenbrunsel, 2011; Greve, Palmer, \& Pozner, 2010; Scherer, Baumann-Pauly, \& Schneider, 2013).

Thus, the purpose of this conceptual paper is to analyze the role of the corporation and its corporate governance in contributing to responsible innovation. We will argue as follows. First, we will propose that responsible innovation is an inherently normative concept that can be defined on the basis of three norms: Avoid harm, do good, and coordinate with others for the sake of protecting the people and the planet (Owen et al., 2013; Voegtlin \& Scherer, 2017; von Schomberg, 2011). We argue that without responsible innovation, it is impossible to meet the grand challenges and to achieve sustainable development (Adams, Jeanrenaud, Bessard, Denyer, \& Overy, 2016; Grinbaum \& Groves, 2013).

Second, we will suggest that corporate governance can help steer business toward innovations that avoid harm and do good. We will discuss legitimacy, effectiveness, and efficiency as criteria with which corporate governance models can be explored with regard to their contributions to responsible innovation and, ultimately, sustainable development. Third, we will argue that participative and reflexive structures are useful mechanisms for addressing the potential contributions and limitations of governance models in general and of current models of corporate governance in particular. With regard to the former we will briefly discuss the governance challenges in the advent of the new coronavirus pandemic (COVID19). With regard to the later we will illustrate how these structures can introduce novel elements to corporate governance and, thus, enable businesses to create innovations that contribute to sustainable development (Driver \& Thompson, 2002; Dryzek \& Pickering, 2017; Gomez \& Korine, 2008; Scherer, Baumann-Pauly, \& Schneider, 2013). 


\section{SUSTAINABLE DEVELOPMENT, GRAND CHALLENGES, AND RESPONSIBLE INNOVATION}

Sustainable development can be defined as "development that meets the needs of the present without compromising the ability of future generations to meet their own needs" (United Nations, 1987). Contemporary conceptions of sustainable development advance three principles: environmental integrity, social equity, and economic prosperity (Bansal, 2005; Marcus \& Fremeth, 2009; Scherer, Palazzo, \& Seidl, 2013). Whether or how these principles can be met is a matter of debate in which the proposed solutions range from small adjustments to massive social transformations of the current institutional and economic order (Hopwood, Mellor, \& O’Brien, 2005).

Grand challenges is the term used to describe massive social and environmental challenges that transcend borders and have (potential or actual) negative effects on large numbers of people (Ferraro et al., 2015; George et al., 2016). Notable examples are global warming, ocean acidification, poverty, and inequality. These challenges are complex, and there are no ready-made solutions. These grand challenges have become a matter of concern not only for intergovernmental actors, such the United Nations (2015), the Organisation for Economic Co-operation and Development (OECD) $(2011,2012)$, and the European Commission (2008; see also Cagnin, Amanatidou, \& Keenan, 2012), and for individual countries (see, e.g., Grand Challenges Canada, 2011), but also for private actors, such as business firms and industry associations, and for civil society actors, such as nongovernmental organizations (NGOs) (Ferraro et al., 2015; George et al., 2016; Nilsson, 2017).

Responsible innovation was originally used as a concept in the context of risk assessments of scientific innovations, especially in nanoscience and nanotechnology research, but was also applied to issues concerning research with human subjects, socio-technical integration, intellectual property, and the ethical and social implications of scientific 
innovation in general (Owen et al., 2013). Responsible innovation has been defined as "a transparent, interactive process by which societal actors and innovators become mutually responsive to each other with a view on the (ethical) acceptability, sustainability and societal desirability of the innovation process and its marketable products" (von Schomberg, 2011, p. 50). Building on this understanding, we argue that responsible innovation should meet three types of responsibility (Voegtlin \& Scherer, 2017): (1) the responsibility to do no harm (Deschamps, 2012; Lee \& Petts, 2013), (2) the responsibility to do good (Stahl \& Sully de Luque, 2014), and (3) responsible governance ${ }^{1}$ (Jordan, 2008; Scherer \& Palazzo, 2011), which involves establishing institutions, structures, and procedures on multiple levels in order to facilitate innovations that fulfill (1) and (2). Governance is thus a meta-responsibility and key to achieving responsible innovation (Voegtlin \& Scherer, 2017).

This understanding differs from social innovation in management research, which is defined as "innovative activities and services that are motivated by the goal of meeting a social need and that are predominantly diffused through organizations whose primary purposes are social" (Mulgan, 2006, p. 146). The understanding of responsible innovation is broader, as it considers all kinds of public, private, and civil society actors and types of collaborations between these as possible innovators, not just particular types of organizations. Furthermore, responsible innovation is distinct, as innovations are subjected to a deliberative control process. Specifically, responsible governance requires governance structures at various levels (e.g., global, societal, corporate) that facilitate an inclusive process of collective will formation on the goals and means and the societal acceptability of innovations (Stilgoe, Owen, \& Macnaghten, 2013; Voegtlin \& Scherer, 2017). This also helps society to consider how the trade-offs between conflicting collective goals (e.g. potential trade-offs between

\footnotetext{
${ }^{1}$ Voegtlin and Scherer (2017) used the term governance responsibility to refer to this aspect of responsible innovation. Throughout the paper, we will use responsible governance and governance responsibility synonymously.
} 
efficiency, stability, and justice or public health) should be managed and to determine what levels of risk or harm should be accepted when regulating financial markets (Marti \& Scherer, 2016) or restricting economic and social exchange during a pandemic such as the current COVID-19 (Fottrell, 2020; Portes, 2020). In contrast, social innovation is created and diffused paternalistically by organizations with prosocial motivations that do not necessarily include those in need in their decision-making process or governance structures.

Pertinent examples of responsible innovation can be found in new information and communication technologies (ICT). These technologies have great potential to contribute to sustainable development and to address grand challenges. At the same time, companies and public authorities that develop and implement ICT innovations need to be aware of the potential harmful consequences (Zuboff, 2015).

One area where ICT innovations can contribute to mitigating grand challenges is the use of ICT in caring for elderly people (Stahl, 2018). The aging population is one of the grand challenges, becoming manifest for instance in the challenge of how to take care of a growing elderly population with fewer and fewer younger people. In this regard, ICT may for instance be used to help to overcome loneliness or monitor the use of drugs. At the same time, it may increase feelings of loneliness if the technology replaces personal contact (Stahl, 2018). Evonods is a company that developed an automatic medicine dispensing service for persons with chronic conditions or dementia. The service "guides the client to take the right dose of medication at the right time, which considerably improves the client's well-being and sense of independence" (Responsible Industry Consortium, 2018, p. 5). This is an innovation that aims to do good.

Furthermore, ICT can be used to track the movements of individuals and their social relationships during a pandemic to control the spread of the disease. Again, this is an innovation that has potential positive public health implications, especially in a crisis, as is the case with the current COVID-19 pandemic. Yet, the collection of personal data and the 
tracking of individuals undermines individual liberties and may be abused by business actors or public authorities when applied outside the narrow realm of combating an infectious disease (Fussell, 2020).

Obviously, innovations based on ICT touch on sensitive areas with regard to societal expectations and individual rights. There are aspects that can be perceived as harmful, such as the potential violation of privacy rights and the rights to freedom of movement and selfdetermination (Richards, 2013). Restrictions of individual rights can only be justified when they are based on legal rules (e.g. when the law mandates such restrictions during an epidemic) and determined in a process of democratic governance, where the benefits and harms of such measures are weighed against each other and all interests and no other less intrusive measures are available. It also touches on questions of fairness and equal access to the benefits of technology and public health care (Responsible Industry Consortium, 2018) and to the process of collective will formation in general (Habermas, 1998).

In this regard, corporate governance should facilitate a process that allows the company to develop the innovation while taking societal needs and fears into consideration, thereby increasing its potential for doing good and decreasing its potential for causing harm, and thus, ultimately, enabling a contribution to sustainable development. In the case of Evonods, the company included stakeholders early on in the innovation process and continued the dialogue throughout to ensure societal acceptability (Responsible Industry Consortium, 2018). In the case of tracking smartphone data to fight the COVID-19 pandemic, network providers in some democratic states have started to cooperate with public authorities to provide only anonymized data that allow authorities to draw implications on the spread of the disease but not to identify individuals (for the case of Swisscom in Switzerland see Bräuer, 2020).

To summarize, responsible innovation is the framework within which governance facilitates innovations that avoid harm and do good. These innovations, in turn, contribute to 
sustainable development. In the following, we will therefore make the distinction between responsible innovation as the meta-framework on one hand and organizational innovations that avoid harm/do good as the outcomes of responsible governance on the other. These organizational outcomes are novel behaviors, processes, products, and services (Thompson, 1965) that contribute positively to the welfare of society and the well-being of the planet while reducing the harmful consequences of social and economic exchange (see Figure 1).

Insert Figure 1 about here

Consequently, transforming governance and institutions at all levels so that they serve the goals of sustainable development and provide remedies for the problems that the grand challenges pose is essential for responsible innovation (Cagnin et al., 2012; Nilsson, 2017; United Nations, 2015). This transformation has to take place at the level of global governance, the level of national governance, and the level of corporate governance, which is the focus of our paper. The aim of transforming governance structures is clear: The process of innovation should not be optimized primarily for the sake of business interests and corporate financial growth, but to address the grand challenges, promote sustainability, and serve the public interest (Nilsson, 2017).

\section{CORPORATE GOVERNANCE FOR RESPONSIBLE INNOVATION}

In capitalist societies the decision-making processes of corporations are influenced and conditioned by the logic of wealth maximization, which is deeply embedded in the economic and legal institutions (Williamson, 1985) and in the corporate governance structures of businesses (Jensen \& Meckling, 1975). However, it is unclear whether the incentive mechanisms in capitalist societies support or impede innovations that contribute to sustainable development and whether, how, and on what level governance structures should be reformed (e.g., with regard to green innovations see the debate between Marcus \& Fremeth, 2009, and Siegel, 2009). The literature on corporate governance and corporate responsibility documents 
various approaches to this question (e.g., Aguilera \& Jackson, 2010; Claessens \& Yurtoglu, 2012; Filatotchev \& Nakajima, 2014). In the following, we will briefly examine the contributions and limitations of these approaches, focusing on evaluating their capacity to facilitate innovations that avoid harm and do good. Our central question is this: How and under what conditions can the internal governance structures of business firms facilitate innovations that address the grand challenges we have outlined, contribute to the well-being of society, and are conducive to sustainable development?

In this conceptual paper we will draw on three dimensions-legitimacy, effectiveness, and efficiency - to answer this question and to evaluate the role of corporate governance in responsible innovation. These three dimensions are widely used in the political governance literature to analyze the effects of alternative governance mechanisms with regard to whether the results are socially accepted, meet collective goals, and use appropriate means (Folke, Hahn, Olsson, \& Norberg, 2005; Fung, 2006; Sorensen \& Torfing, 2009; Swyngedouw, 2006). The dimensions thereby also mirror key aspects of what we have defined as responsible innovation - that is, the acceptability, sustainability, and feasibility of the innovation process and its outcomes.

In the public realm, governance can be understood as the steering mechanism by which social systems manage their public affairs and generate and implement collective decisions to enhance societal well-being (Folke et al., 2005; Jordan, 2008). Corporate governance describes the steering mechanisms that corporations use to manage their private affairs and to generate and oversee corporate decisions that meet the expectations of the constituencies of the corporation (Claessens \& Yurtoglu, 2012). To what end private corporations should be managed, what interests should be taken into account, and how conflicts should be resolved is a matter of debate: Some argue that businesses should focus exclusively on the shareholders' interests (e.g., Jensen, 2002; Sundaram \& Inkpen, 2004); others suggest that businesses should integrate the concerns of various stakeholders (Aguilera 
\& Jackson, 2003; Cadbury, 2003; Mitchell, Weaver, Agle, Bailey, \& Carlson, 2016) or demand that businesses focus directly on societal well-being (Ulrich, 2008). The normative position of our paper is clear: Corporate governance should influence the corporate innovation process so that the outcomes are socially acceptable (legitimacy), meet sustainable development goals (effectiveness), and use appropriate means (efficiency) so that the resulting innovations avoid harm and do good to society and the planet.

The capitalist conception of society is characterized by the clear separation of roles (Friedman, 1970; Jensen, 2002; Sundaram \& Inkpen, 2004): The political and the legal systems generate and enforce legitimate legal frameworks that put restrictions on economic actors to ensure that the results of their profit-oriented behavior contribute to the well-being of society. Within these legal frameworks, corporations focus on their efficiency without the obligation to take on any social or political responsibilities (Friedman, 1970). This idea of how capitalist societies function is still widely accepted as a role model for profit-oriented businesses and, thus, the majority of economic actors.

From this perspective, innovation, whether it concerns products or processes, can have only one aim: to protect or enhance the competitive advantage of firms in order to maximize their profits. However, when the behavior of corporations has a negative impact on society and state institutions are unable or unwilling to regulate businesses or compensate externalities - that is, to bear the costs of the negative societal side effects of doing business - via the legal system, the assumption that the responsibilities of businesses are entirely separate from societal well-being becomes untenable (Palazzo \& Scherer, 2006; Scherer \& Palazzo, 2007). As these institutional failures have become the rule rather than the exception, it is no longer justifiable for private businesses to focus exclusively on efficiency, profit, and the interests of shareholders (Bénabou \& Tirole, 2010; Stone, 1975). Consequently, corporations adjust their role (Matten \& Crane, 2005): They provide public goods, address externalities, and thus become public actors, subject to the principles of 
democratic governance and responsible toward society (Scherer \& Palazzo, 2011; Ulrich, 2008). This also has an effect on the role of innovation, whose purpose can no longer be aimed exclusively at protecting the competitive position of a firm but must increasingly comprise direct contributions to societal well-being (Voegtlin \& Scherer, 2017).

In a globalized world the capitalist conception becomes even more questionable, as significant parts of global value chains have been shifted to "fragile states" that have deficient governance institutions and lack the willingness and capacity to protect the interest of their citizens and the intactness of the planet (Fund for Peace, 2019; Naudé, SantosPaulino, \& McGillivray, 2011). In some economically significant yet oppressive and undemocratic countries, workers and citizens who claim their rights, journalists and politicians who oppose the government, and scientists and social activists who criticize economic or environmental policy or human rights conditions not only risk suppression, such as being silenced or fired, but also more repressive measures, such as imprisonment, forced disappearance, and murder.

Today many business operations take place in such countries where there is limited democratic control and rule of law. ${ }^{3}$ This becomes evident in the extent to which fragile states export merchandise and commodities (see the number of fragile states listed in the "top 30

\footnotetext{
2 The Fund for Peace and the journal Foreign Policy publish the annual Fragile States Index in which currently 178 countries are assessed on 12 social, economic, political, and military indicators (see https:// fragilestatesindex.org/) and are positioned on a scale ranging from "very sustainable" to "very high alert." In 2019, 119 out of 178 nation states were listed in the categories "warning," "elevated warning," "high warning," "alert," "high alert," or "very high alert," and could thus be considered fragile states. By comparison, only 59 states were listed as "stable" or better (Fund for Peace, 2019, pp. 6-7).

${ }^{3}$ Multinational corporations operate in heterogeneous institutional environments that include failed and weak states, strong but oppressive states, and a large variety of more or less democratic rule-of-law states (Scherer, 2018; Scherer, Palazzo, \& Seidl, 2013). At the same time, many "fragile states" that lack democratic and rule-of-law institutions (Fund for Peace, 2019; Naud'e et al., 2011) are economically potent and are thus listed among the preferred host economies of foreign direct investment inflows (see UNCTAD World Investment Report, 2019, where PR China, Brazil, India, Mexico, Indonesia, Israel, Vietnam, the Russian Federation, and Colombia are listed among the top 20 host economies of foreign direct investment inflows and are at the same time listed in the "warning" category or in a worse category in the 2019 Fragile States Index report) or important merchandise export nations (see the WTO World Trade Statistical Review, 2019, where PR China, Mexico, the Russian Federation, India, Saudi Arabia, Thailand, Malaysia, Vietnam, Brazil, and Indonesia are listed among the top 30 merchandise export nations and are at the same time listed in the "warning" category or in a worse category in the Fragile States Index report of 2019).
} 
merchandise export nations" in the World Trade Organization's World Trade Statistical Review, 2019, p. 100) or have become the preferred locations for foreign direct investments (see the number of fragile states listed in the "top 20 host economies of foreign direct investment inflows" in the UNCTAD World Investment Report, 2019, p. 4). Under these conditions humankind cannot wait for fragile states to eventually become reformed and democratic. Rather, business firms (and other nonstate actors) have to step in and fill the gaps to protect people and the planet (Kolk \& Lenfant, 2015; Scherer, 2018; Scherer \& Palazzo, 2011).

In light of state failures, corporations, among other private and civil society actors and transnational organizations, have the important role of generating and diffusing innovations that contribute to sustainable development. Consequently, we will evaluate current approaches to corporate governance and address three questions relating to the aforementioned dimensions of legitimacy, effectiveness, and efficiency.

Our first question is this: Which structures of corporate governance help businesses maintain the legitimacy of innovations? Legitimacy concerns the ethical dimension of governance and is defined as (rationally motivated) social acceptance (Suchman, 1995). In a general sense, "legitimacy ... prescribes the process by which ... collective decisions can be morally justified to those who are bound by them" (Thompson, 2008, p. 502). Suchman (1995) distinguished three sources of social acceptance: perception of benefit (pragmatic legitimacy), compliance with taken-for-granted expectations (cognitive legitimacy), and explicit moral discourse (moral legitimacy). To answer the first question, we have to examine the extent to which changes in corporate behavior, processes, products, and services are socially acceptable or can be made socially acceptable.

The second question we will address is this: Which structures of corporate governance help businesses enhance the effectiveness of innovations? Effectiveness is defined as "doing the right things" (Rämö, 2002, p. 572, with reference to Drucker, 1974; for a discussion on 
the effectiveness of corporate governance, see Aguilera, Filatotchev, Gospel, \& Jackson, 2008). This definition reflects the political dimension of governance and puts the focus on defining the collective goals toward which corporations should aim their innovations and business strategies: "Networking with stakeholders in the identification and use of common means will tend to increase efficiency, and networking with stakeholders in the pursuit of common ends will tend to enhance effectiveness" (Sorensen \& Torfing, 2009, pp. 239-240). When answering the second question, we have to consider the goals of corporate innovation and explore how businesses should determine their priorities with regard to profitability and sustainability (such as the 17 Sustainable Development Goals of the United Nations; United Nations, 2015).

Our third and final question is this: Which structures of corporate governance help businesses increase the efficiency of corporate innovations? Efficiency relates to the economic or technical dimension of corporate governance and can be defined as "doing things right" (Rämö, 2002, p. 572, with reference to Drucker, 1974). To answer the third question, we need to investigate how businesses can develop the best measures to efficiently achieve the goals and targets previously defined. The processes through which businesses manage these tasks generally rely on the principles of economic rationality, which determine the best means for given ends. However, as research in decision science has shown (e.g., Mintzberg \& Westley, 2001; Rittel \& Webber, 1973), linear decision-making processes, which involve defining the goals first and only then selecting the means by which to achieve them, are not feasible in conditions of high complexity. In such cases the order may be reversed, so that goals are determined according to available means. Furthermore, the processes of goal definition and means selection may run in parallel or be interlinked and may involve several actors.

Therefore, we have to discuss how governance structures can facilitate these processes and increase efficiency for the sake of sustainable development and societal well-being (Folke et al., 2005). 
In the next section, we analyze prevalent corporate governance approaches alongside the three dimensions of legitimacy, effectiveness, and efficiency.

\section{THREE APPROACHES TO CORPORATE GOVERNANCE:}

\section{CONTRIBUTIONS AND LIMITATIONS FOR RESPONSIBLE INNOVATION}

In the literature on corporate governance, monolithic approaches that focus on capital interest compete with more inclusive approaches that take into account a broader range of stakeholders (Aguilera \& Jackson, 2010; Claessens \& Yurtoglu, 2012; Hambrick, Werder, \& Zajac, 2008). Three broad perspectives contribute to the debate on corporate governance and its implications for corporate responsibilities: (1) the shareholder value approach, (2) the stakeholder approach, and (3) the political CSR approach. Table 1 presents an overview of the assumptions made by these approaches and their contributions and limitations with regard to responsible innovation. The extant literature on corporate governance contains many other approaches that build on behavioral, institutional, or economic perspectives; focus on various levels of analysis; and are either more inward looking, emphasizing the structural or behavioral aspects, or more outward looking, exploring the institutional aspects (Hambrick et al., 2008).

Insert Table 1 about here

Important in this respect are the behavioral corporate governance approach, which explores the influence of formal and informal incentives and power structures on individual behavior (Wiseman \& Gomez-Mejia, 1998); the comparative approach, which examines the varieties of capitalist institutions and their implications for corporate governance (Hall \& Soskice, 2001; Whitley, 1999); and the actor-centered corporate governance approach, which establishes a link between these levels of analysis (Aguilera \& Jackson, 2003; Westphal \& Zajac, 2013). The three perspectives we focus on are orthogonal to this debate and signify in 
an ideal-typical way extreme positions with regard to the inclusion or exclusion of various stakeholders, how value conflicts between stakeholders are resolved, and how corporate decisions reflect effects on societal well-being and the protection of the planet.

\section{The Shareholder Value Approach to Corporate Governance}

The shareholder value approach focuses on protecting the interests of the owners of the firm (Bebchuk \& Weisbach, 2010; Jensen \& Meckling, 1976) and on "the ways in which suppliers of finance to corporations assure themselves of getting a return on their investment" (Shleifer \& Vishny, 1997, p. 787; emphasis in the original omitted here). Whereas all other stakeholders are protected by contracts and regulations, the owners of the firm are considered to be the residual claimants (Sundaraman \& Inkpen, 2004). The assumption underlying this approach is that corporate behavior focuses on rent seeking, while "perfect government" (Besley \& Ghatak, 2007, p. 1660) involves defining and enforcing regulations that restrict corporate behavior and, at the same time, foster the development of corporate innovations that contribute to the public interest and do not harm society. According to the shareholder value approach, pursuing innovation for sustainable development is not the responsibility of businesses: Their sole responsibility is to make profit, and any innovation is subject to this goal (Friedman, 1970). Even recent studies espousing the creating shared value approach do not depart from this perspective (Porter \& Kramer, 2011). These too suggest or imply that social and environmental concerns have no intrinsic value and matter only to the extent that they influence financial performance (see, critically, Crane, Palazzo, Spence, \& Matten, 2014).

Consequently, we propose that the shareholder value model of corporate governance can be a very powerful means within the framework of responsible innovation if government provides the right incentives to foster innovations that avoid harm and, at the same time, do good (e.g., if it provides subsidies for investments in environmentally friendly technologies or tightens regulations on working conditions, etc.), and if firms are allowed to reap the financial 
benefits from their innovations (e.g., by protecting ownership rights through patents, etc.). However, these conditions are difficult to achieve in a globalized environment, as we will illustrate in the following.

With regard to the three dimensions we discuss in this paper-legitimacy, effectiveness, and efficiency - the shareholder value approach to corporate governance is limited. The shareholder value approach rests on the assumption that corporations can and should focus on making profit because governments can, by and large, adequately regulate corporate activities to ensure that the public interest is served (Sundaram \& Inkpen, 2004). However, in practice, even when companies operate within and comply with a regulatory system, this does not suffice to demonstrate their legitimacy. This is because companies often do business under conditions of state failure (Bénabour \& Tirole, 2010; Scherer \& Palazzo, 2007; Stone, 1975) or in fragile states (Fund for Peace, 2019; Kolk \& Lenfant, 2015; Scherer \& Palazzo, 2011); in both cases the state is unable or unwilling to define and enforce regulations that channel the value-generating strategies of business firms toward societal wellbeing and sustainable development. Therefore, to demonstrate legitimacy, companies have to either adapt their behavior to the expectations of their critics or engage in moral discourse with those who are negatively affected by their behavior (Scherer, Palazzo, \& Seidl, 2013; Suchman, 1995).

The effectiveness of the shareholder governance model is also questionable where sustainable development is concerned. If effectiveness is understood as "doing the right things" (Rämö, 2002, p. 572, with reference to Drucker, 1974), it means generating and diffusing innovations that contribute to the welfare of (and do not harm) society. This understanding of effectiveness highlights two problems with the shareholder value model. First, because national law and regulations have a very limited impact outside a country's national borders, both the incentives for firms operating globally to pursue innovation that promotes sustainability and the disincentives in the form of sanctions against such businesses 
whose activities harm society are also limited. Second, the corporate decision-making process focuses exclusively on the interests of shareholders. Consequently, external stakeholders whose interests lie in promoting social or environmental welfare are normally excluded from corporate decisions. As a result, corporate innovations will primarily serve the financial interests of shareholders and only secondarily the interests of society, but only if these happen to increase corporate profits (see, e.g., Porter \& Kramer, 2011; Siegel, 2009).

With regard to the efficiency of the shareholder governance model, the question is whether this model leads to innovations that help achieve predefined goals. The shareholder value governance model puts great emphasis on enhancing profits and cutting costs to create shareholder value. The idea is that businesses should install incentives and control systems that motivate managers to select strategies that maximize shareholder value (Jensen \& Murphy, 1990). One problem with this approach is that when corporate goals conflict with the goals of sustainable development, efficiency essentially translates into putting in place measures that, in terms of sustainability or societal well-being, serve the wrong goals. A further potential problem is that the simple models of incentives this approach advocates prove inefficient in settings characterized by high complexity and ambiguity because their consequences cannot be accurately predicted (Kerr, 1975).

In fact, the widespread pay-for-performance systems have come under scrutiny not only because they raise many questions regarding fairness but also because of their negative side effects (Frey \& Osterloh, 2005). There is evidence that such schemes may discourage intrinsic motivation (Deci, Koestner, \& Ryan, 1999; Frey \& Jegen, 2001), impede innovation (Kohn, 1993), and undermine prosocial behavior (Benabou \& Tirole, 2006; Fuster \& Meier, 2010), all of which are important for responsible innovation.

\section{The Stakeholder Approach to Corporate Governance}

The stakeholder approach rejects the narrow view of the shareholder approach (Blair, 1995; Driver \& Thompson, 2002; Lazonik \& O’Sullivan, 2000; Letza, Sun, \& Kirkbride, 
2004). Rather than focusing primarily on the interests of the owners of the firm, the stakeholder approach acknowledges the interests of a wide range of stakeholders who are affected by or can affect the course a firm pursues (Freeman, 1984). The stakeholder approach to corporate governance proposes that business firms should allow nonshareholding stakeholders to contribute to corporate decisions. Rather than focusing exclusively on profits, the management ought to assume the role of moderator and balance the various (possibly incompatible) concerns and interests of different stakeholders within and outside the firm, and then define a course of action that satisfies the interests of all stakeholders (Blair \& Stout, 1999, 2001; Cadbury, 2003). This is an important contribution toward developing an alternative to the shareholder value approach.

The stakeholder approach is especially powerful in contributing to responsible innovation when those stakeholders who take an interest in societal welfare and sustainable development are integrated in corporate decision-making procedures (e.g., as an advisory panel to the board of directors or when socially responsible investors can hold large blocks of shares). However, this often depends on the attributes of stakeholders. We will illustrate the limitations of the stakeholder approach alongside the dimensions of legitimacy, effectiveness, and efficiency.

The stakeholder approach considers legitimacy to be an important factor in defining the strategic course of the firm (Phillips, 2003). Yet this is either based on the normative premise that all stakeholders should be included (Donaldson \& Preston, 1995) or considered from a strategic or instrumental perspective, where firms take into account the expectations of stakeholders depending on their power and legitimacy and on the urgency of their demands (Mitchell, Agle, \& Wood, 1997). In the latter case, this often leads to a prioritization of the demands of the most powerful stakeholders; as a consequence, firms are likely to ignore the legitimate or urgent concerns of less powerful stakeholders (Agle, Mitchell, \& Sonnenfeld, 1999). 
In the former case, normative stakeholder theory does not sufficiently take into account the heterogeneity of the institutional environment (Pache \& Santos, 2010; Waddock, 2008) and the legal and moral fragmentation (Scherer, 2015; Teubner \& Korth, 2012) of the global business setting. Countries have very different legal systems and regulations for issues such as taxation, the environment, product safety, and workers' rights (see, e.g., Michaels, 2009; Young, 2012), and many businesses operate in fragile states where legal institutions and the rule of law in general are weak (Fund for Peace, 2019; Kolk \& Lenfant, 2015; Scherer \& Palazzo, 2011). In addition, the considerable pluralism of social norms, values, and lifestyles in different cultures means that firms are confronted with the diverse and possibly incommensurable moral expectations of various stakeholders (see, e.g., Scherer, 2015). The stakeholder approach has yet to propose mechanisms that will allow businesses to integrate diverse institutional and moral concerns (see, e.g., Brès, Raufflet, \& Boghossian, 2018) to secure the legitimacy of responsible innovation.

When it comes to identifying "the right things to do" (Rämö, 2002, p. 572, with reference to Drucker, 1974) and, therefore, to issues of effectiveness, the strategic stakeholder approach would, on one hand, imply that firms give priority to sustainability goals only when these are put forward by powerful stakeholders. As a result, R\&D and innovation strategies serve sustainability either when the most powerful stakeholders' goals promote sustainable development or when stakeholders directly push business firms to produce innovations that benefit society (Spar \& La Mure, 2003). Therefore, the effectiveness of the stakeholder approach with regard to sustainability depends on whether stakeholders have both compatible goals and sufficient power to influence corporate decisions. On the other hand, the normative stakeholder approach still needs to specify in greater detail how to address the goals of sustainable development and the grand challenges that impede their realization (Ferraro et al., 2015; George et al., 2016). 
In relation to efficiency, from the perspective of both normative and strategic stakeholder theory, "doing things right," and thus promoting the development and diffusion of responsible innovations, depends on the knowledge and competence of various stakeholders, on their willingness to contribute their assets, and on the availability of a governance mechanism that can convert all these factors into social or technological innovations that aid sustainable development.

\section{The Political CSR Approach to Corporate Governance}

The political CSR approach treats business firms as political actors that contribute to the production of public goods where governments are unable or unwilling to do so (Matten \& Crane, 2005; Scherer \& Palazzo, 2007, 2011; Scherer, Rasche, Palazzo, \& Spicer, 2016). Studies that follow the political CSR approach tend to discuss the role of businesses in public governance. These studies focus mainly on the macro level of global governance. However, there have also been studies on the internal structures and procedures that business firms employ in order to fill such gaps in global governance (Baumann-Pauly \& Scherer, 2013; Scherer et al., 2016). And there have been initial studies on the forms that corporate governance could take seen from a political CSR perspective (see Mena \& Palazzo, 2012; Scherer, Baumann-Pauly, \& Schneider, 2013; Schneider \& Scherer, 2015). Moreover, studies have explored the potential of making corporate governance more democratic (Driver \& Thompson, 2002; Gomez \& Korine, 2008; Parker, 2002).

The work that tackles these subjects focuses mainly on two areas: the problems of legitimacy that corporate intervention in public issues entails (e.g., Parker, 2002) and how deliberation in multistakeholder networks and the democratization of corporate governance can (at least partly) compensate for institutional deficiencies in a company's environment (e.g., Scherer, Baumann-Pauly, \& Schneider, 2013). Despite some emphasis on the implications that businesses serving as public actors have for responsible innovation (Voegtlin \& Scherer, 2017), this approach still needs to be further developed. 
The advantage the political CSR approach offers with regard to the link between corporate governance and responsible innovation is that it provides a mechanism for integrating the various stakeholders - not only the powerful ones - and a mode of decision making that allows for multiple objectives - not only financial ones - to be taken into consideration. More specifically, by building on the foundation of deliberative democracy, it can offer corporate governance innovative possibilities for stakeholder integration (e.g., by introducing modes of decision making based on mutual agreement rather than just majority voting, offering access to stakeholders with legitimate interests by institutionalizing stakeholder panels, or by encouraging socially responsible investors to become shareholders). We illustrate these advantages but also the current limitations alongside the three dimensions of legitimacy, effectiveness, and efficiency below.

With regard to legitimacy, adherents of the political CSR approach argue that corporations cannot rely solely on complying with legal norms and moral expectations, because in a globalized world laws and regulations are fragmented (Teubner \& Korth, 2012) and moral norms are heterogeneous (Palazzo \& Scherer, 2006). According to this view, corporations have three choices (Scherer, Palazzo, \& Seidl, 2013). First, they can follow a manipulation strategy; that is, they can develop a legitimacy strategy to manage the expectations of their most important stakeholders. Second, they can follow an adaptation strategy and selectively adapt their overall business strategy to the expectations of certain constituencies. Third, they can pursue a moral argumentation strategy and actively engage in discourses on the social acceptability of their business strategies and behaviors in order to maintain or repair their legitimacy. All three types of strategies can be used both reactively and proactively (Oliver, 1991).

With regard to effectiveness, proponents of political CSR reject the shareholder value model and the exclusive focus on economic performance (Scherer \& Palazzo, 2007). They instead propose a more balanced approach that integrates economic, social, and 
environmental goals and multiple criteria for decision making, including efficiency, stability, and justice (see, e.g., Marti \& Scherer, 2016). From this perspective, "doing the right things" (Rämö, 2002, p., 572, with reference to Drucker, 1974) means that corporations should not harm society and should contribute directly to societal well-being. Consequently, corporate innovation should not be exclusively influenced by financial motives but should, on the contrary, address a range of societal problems and serve the public interest (see, e.g., Marti \& Scherer, 2016). Unlike stakeholder theory, political CSR provides a mechanism that is based on deliberation and offers a procedure that helps with prioritizing goals.

With regard to efficiency — that is, "doing things right” (Rämö, 2002, p. 572, with reference to Drucker, 1974) — the political CSR approach suggests that firms need to design their governance structures with an eye toward facilitating an organizational learning process (Palazzo \& Scherer, 2010), the so-called "triple-loop learning” (Argyris, 1977; Tosey, Visser, \& Saunders, 2012). This means that learning has to take place on three levels: Firms need to modify not only (1) the means they employ but also (2) the ends they pursue and (3) the governance structures in which their decisions and actions are embedded.

The policies associated with climate change illustrate the challenges that the tripleloop approach poses (Levin, Cashore, Bernstein, \& Auld, 2012). In stage one, firms focused on changing their routines in order to save energy; in stage two, firms changed their policies, which led them to revise their emission goals. In both regards, isomorphic pressures could be observed that made firms adopt the latest industry standards over time (e.g., Levy \& Kolk, 2002). Finally, in stage three, governments changed both the regulations that govern climate change and the way regulations are enacted; in other words, they changed both the discourse and the governance structures that relate to the issue of climate change (Gupta, 2016). This example also illustrates the potential competitive advantages firms can gain if they follow a proactive learning approach with regard to sustainability: Those firms can create first-mover 
advantages and can preempt governmental regulation (Reid \& Toffel, 2009; Tetrault Sirsly \& Lamertz, 2008).

While current research on political CSR provides only initial answers with regard to the form that a corporate governance model that encourages firms to engage in responsible innovation might take (see, e.g., Scherer, Baumann-Pauly, \& Schneider, 2013), we consider its foundation of deliberative democracy a promising starting point. To address the open questions of the political CSR approach, we develop the deliberative conception further and turn to the idea of corporate governance as reflexive and participative governance.

\section{CORPORATE GOVERNANCE AS REFLEXIVE AND PARTICIPATIVE GOVERNANCE}

In the literature on ecology and environmental policy there are different approaches to defining governance structures that facilitate innovation with regard to environmental and social issues (Dryzek \& Pickering, 2017; Meadowcroft \& Steurer, 2013; Reed, 2008). Reed (2008) reviewed some of these approaches and derived a list of best practices, emphasizing participation, representation, learning, and the integration of local and scientific knowledge. Obviously, these approaches build on assumptions similar to those in political CSR. Dryzek and Pickering (2017) advanced reflexivity as a key concept of governance (also see Beck, 1992; Meadowcroft \& Steurer, 2013). They defined reflexivity as "the ability of a structure, process, or set of ideas to reconfigure itself in response to reflection on its performance" (Dryzek \& Pickering, 2017, p. 353) and suggested that deliberation is a driver of reflexivity and thus enables reflexive governance.

Deliberation is understood as "debate and discussion aimed at producing reasonable, well-informed opinions in which participants are willing to revise preferences in light of discussion, new information, and claims made by fellow participants" (Chambers, 2003, p. 309). This concept, on which political CSR is also founded (Scherer \& Palazzo, 2007), has been central in the theory of deliberative democracy (Chambers, 2003; Dryzek, 1990; 
Habermas, 1998, 2001; Thompson, 2008). Whereas traditional liberal models of democratic governance focus exclusively on institutionalized forms of politics (e.g., parliaments, parties, elections) (Elster, 1986) ${ }^{4}$, deliberative democracy involves the shaping of public policy in discursive processes that take place above and beyond state institutions and involve both state and nonstate actors (Fung, 2003a, 2006; Habermas, 1998, 2001; Roberts, 2004). This makes deliberative democracy suitable for studying collective decision making in relation to global public issues and to the grand challenges (George et al., 2016; Levin et al., 2012), especially in cases where fragile states, weak institutions, nonstate actors, and "messy" problems are involved (Rittel \& Webber, 1973, p. 155; see also Palazzo \& Scherer, 2006; Scherer \& Palazzo, 2007, 2011). And, indeed, deliberative approaches to participative decision making have been applied to collective issues such as renewable energy (Fast, 2013), climate change (Lidskog \& Elander, 2010), land use policy (van den Hove, 2006), international labor standards (Fung, 2003b), and palm oil production (Schouten, Leroy, \& Glasbergen, 2012).

The theory of deliberative democracy advances the idea that democratic decision making should not be conceived as the mere aggregation of given preferences through the institutionalized mechanisms of election, representation, and the counting of votes (rather than arguments) (Elster, 1986). Deliberative democracy emphasizes the role of deliberations in the process of forming and changing preferences on public issues and explores the variety of communicative conditions and mechanisms to determine collective decisions (Habermas,

\footnotetext{
${ }^{4}$ With regard to the word "liberal" we build on the language use in the literature on political philosophy that puts emphasis on individual liberty as the main concern of social theory. Accordingly, a "liberal" conception of democracy focuses on how and under what conditions the given and irreconcilable preferences of individuals can be aggregated into collective decisions by way of elections, majority votes, and representations (Elster, 1986; Habermas, 1998, 2001). This deviates from the commonsense use of the word in the United States where "liberal" means "left of center" in political terms. A deliberative conception of democracy by contrast puts emphasis on the communicative processes that lead to the formation and transformation of individual preferences. It assumes that preferences are not simply "given" but are formed by communications in the first place and that they are in principle open for contestation, debate, and change.
} 
1998, 2001). The assumption is that collective decisions will be improved if they are based on reason and argument (instead of the arbitrary exercise of power) and take into account the available knowledge and the interests and perspectives of those who are potentially affected by the decisions (Thompson, 2008).

The theory of deliberative democracy can help us further develop the idea of reflexive governance and spell out principles for analyzing and changing governance structures on the firm level. Table 2 offers an overview of the elements of reflexive and participative corporate governance that will be elaborated in the following section.

Insert Table 2 about here

\section{Challenges of Reflexive Governance}

If reflexive governance is to foster innovation in a legitimate, effective, and efficient way, it has to deal with at least three challenges (Dryzek \& Pickering, 2017): participation and expertise, diversity and consensus, and polycentricity and centralization.

Participation and expertise. Reflexive governance requires two inputs of equal importance that are potentially in conflict with each other: Civic participation makes sure that governance takes into account the interests and perspectives of different societal actors and makes use of diverse knowledge bases when addressing collective problems (Meadowcraft \& Steurer, 2013). This applies especially to economic and societal developments when members of society in political processes of collective will-formation develop new public policies or point to the harmful consequences and side effects of previous policies (Beck, 1992). Complex problems and grand challenges, such as climate change or pandemics, in turn, require the knowledge and insights of experts who are capable of identifying the problems, their causes, and potential mechanisms to ameliorate them (Reid et al., 2010). However, members of society or officials in the administrative or political system may consider themselves competent without taking into consideration the insights of experts from science, 
such as by emphasizing their personal experience and downplaying the role of scientific evidence (Dryzek \& Pickering, 2017). This effect can be amplified by the official communication of the government (with regard to climate change and the energy policy of the Trump administration in the United States, see McGuire, 2017; concerning the neglect of the emerging COVID-19 pandemic by the Brazilian president Bolsonaro, see Friedman, 2020). In turn, experts focusing on technocratic rationality tend to emphasize the efficiency of means while leaving aside public policy concerns or underestimating tradeoffs between competing public goals (Luke, 2011; Marti \& Scherer, 2016). Both effects can lead to a shutting down of reflexivity (Dryzek \& Pickering, 2017)

Diversity and consensus. The tension between diversity and consensus in governance refers to the fact that reflexive governance needs to be permanently open to new insights and multiple perspectives and must be able to question the status quo (i.e., checking the prevailing values, practices, structures, and behaviors concerning their legitimacy, effectiveness or efficiency). At the same time, governance should not remain in a state of permanent reflection. Rather, collective response requires that decisions be made and that reflections give way to action (Voß, Kemp, \& Bauknecht, 2006). Therefore, public policy as much as business policy and strategy have to be made under conditions of conflicting interests and goals, time pressure, and incomplete information, often without the possibility to come to a consensus. The tension is also reflected in the management literature when organizations oscillate between exploration and exploitation (March, 1991) or between innovation and routine (Andriopoulos \& Lewis, 2009). This tension cannot be resolved. Rather, it appears to be a paradox that has to be handled by carefully balancing the options for taking action, applying mechanisms such as precautionary principles, organizational slack and slack resources, or robust action (Beck, 1992; Ferraro, Ezion, Gehman, 2015; Smith \& Lewis, 2011). 
Polycentricity and centralization. The tension between polycentricity and centralization concerns the institutional architecture of governance (Galaz, Crona, Österblom, Olsson, \& Folke, 2012). Should governance resources be pooled in one center, which may facilitate the exchange of information, internal coordination, and effective diffusion and implementation? Or should the resources be decentralized and dispersed over different locations and governance layers so there is a higher probability that something useful might be created or discovered and applied by way of experiment somewhere at the periphery? The latter may be particularly useful for exploring new approaches: "Reflexivity may arise through the ability of individuals and groups to organize sites for innovation and experimentation that are partly insulated from external pressures to conform and compete" (Dryzek \& Pickering, 2017, p. 357). However, decentralization may be an obstacle for the diffusion of ideas and solutions, compared to centralized systems where innovations such as structural or behavioral changes are delegated down the chain of command. This is also a problem in the advent of the current COVID-19 pandemic, where the supply of intensive care capacities and the demand for those are distributed unevenly and the matching of available slack resources with severely sick patients has to be coordinated across different levels of local, national, and international governance by way of negotiation and discourse as no central steering unit is available. Yet decentralized health care systems, such as in Germany, may have some advantages concerning the agility, response time, and availability of slack resources to fight new infectious diseases (Kuras, 2020; Oltermann, 2020).

These tensions are problems that governance needs to address. Introducing deliberative structures into governance, including corporate governance, can help to achieve a balance (Dryzek \& Pickering, 2017). With regard to the tension between participation and expertise, deliberation can ensure the inclusion of a broad base of potentially affected stakeholders and the technocratic knowledge of external experts required for responsible innovation. With regard to diversity and consensus, it allows for both reflection on desired 
goals with stakeholders and a striving for collective action to achieve those goals. With regard to polycentricity and centralization, deliberation is a way to allow for polycentric emergence of innovative ideas in an otherwise hierarchical organizational structure. Next we identify core aspects for the realization of reflexive and participative corporate governance based on deliberative structures.

\section{Participation in Governance}

Research on deliberative democracy has identified various forms of participation that present a continuum between the extremes of the tensions faced by reflexive governance. Fung (2006) discussed three key dimensions of participation in governance (for alternative typologies see Reed, 2008, pp. 2018-2020) that will help us answer the questions of (1) who participates, (2) how participants communicate with each other and make decisions, and (3) how these decisions gain authority and earn the status of collectively binding decisions. These dimensions define the possible space in which participation in governance can take place. The actual form of participation will depend on the issue that needs to be governed, the constraints with regard to time and resources, and the individual and organizational capacity for deliberation of the relevant actors (Irvin \& Stansbury, 2004).

With regard to the question of who participates, Fung (2006) distinguished among various mechanisms for selecting the actors who participate in governance and envisaged participation as a continuum ranging from more inclusive to more exclusive forms of participation, including self-selection, which means that anyone who wishes to take part in deliberation can do so, and selective recruitment, which aims to include individuals who are normally excluded either due to structural or motivational constraints; this can be either active or passive (i.e., by means of structural incentives). Participation can comprise lay stakeholders (nonexpert individuals who have a deep interest in the matter) or professional stakeholders (paid representatives of organized interests). 
With regard to how participants communicate with one another and make decisions, Fung (2006) differentiated among six main modes of engagement, ordered from the least to the most intense. In the first three modes, participants are included in communication, but they are largely excluded from decision making: They (1) remain passive and simply receive information, (2) express their preferences, or have the opportunity to (3) explore, develop, or transform their preferences. In the next two modes, individual participants have a greater influence on collective decision making: In processes of (4) aggregation and bargaining, the conscious preferences of the participants are aggregated into a collective choice; this is often influenced by the participants' power resources. In processes of (5) deliberation and negotiation, the collective decision is based on argumentative interaction. This means that participants try to form joint preferences and to base their collective choices on reasons, arguments, and principles on which (ideally) all can agree. The final mode is (6) technical expertise, whereby experts, who are "officials whose training and professional specialization suits them to solving particular problems" (Fung, 2006, p. 69), define public policies and choices.

With regard to the impact of participation and how the participants' decisions are connected to action, Fung (2006) emphasized the role of authority and influence. The participants in processes of deliberation have various degrees of authority, and this determines the degree of influence they have on public policy through the exercise of direct power. Participants with the least authority engage in the deliberation of public issues for personal benefit and do not expect to influence collective decisions to any substantial degree. In the most direct form of participatory decision making, the participants exercise direct authority, which means that their decisions automatically become binding collective rules, as is the case with referenda. Between these, one can also find influence in the form of providing advice or engaging in co-governing partnerships, where participants and officials jointly define the goals of policies. 


\section{Reflexive Governance in the COVID-19 Pandemic Crisis}

Recent challenges such as the COVID-19 (aka "novel coronavirus") pandemic crisis highlights the need for responsible innovation in governance at a significantly more complex and integrated level than we are currently practicing (Taylor, 2020). Tragically, in a crisis like this, waiting for sufficient data to make crucial public health management decisions would potentially cost too many lives (Fottrell, 2020). Therefore, many countries worldwide have rapidly and massively responded to the pandemic with emergency measures focusing on the demand side of health care.. To flatten the curve of exponentially increasing COVID-19 infections, governments have instituted information campaigns and intensive testing; enforced social distancing and quarantining; tracked infection chains; and closed borders, put restrictions on travelling, and instituted nationwide shutdowns of economic and social life-not to mention the accompanying of gigantic financial aid programs required to support such policies. Hence, to accelerate effective responses to this unprecedented challenge, various societal actors have innovated "on the go" - and the key factor in this new development is deliberative collaboration and the pooling of resources (i.e., assets, material, knowledge)to strengthen the supply side of health care to prepare for the rising tide of COVID-19 patients in serious condition.

Such collaborations can be horizontal or cross-sectoral, i.e., between private, public and civil society actors, aiming at rapidly enlarging the capacity of the health care system. Examples include mobilizing civil and military reserves, producing urgently needed ventilators or protective clothing and masks, developing and testing new diagnostic and therapeutic measures, or providing software applications for detecting the movements and social relationships of individuals for monitoring the spread of the disease or to warn about potentially affected contact persons. In Germany, a number of textile firms have reorganized their operations to produce protective clothing and masks that were formerly outsourced to countries such as China or India (EDANA, 2020). Furthermore, proving once more that necessity is the mother of invention, 
several business firms have developed new diagnosis procedures that can quickly detect a new coronavirus infection or allow for large-scale testing (Rauwald \& Loh, 2020; Roche, 2020). In some countries, such as Switzerland, consortia of software hackers and private firms collaborate in developing smartphone Apps that help control the spread of the disease but are compliant with privacy rights (Betschon, 2020).

However, vertical collaborations are also needed, e.g., between the local, state, national and international levels of governance, to produce structural and procedural innovations that enable healthcare systems to respond rapidly to vital needs. The nature of this pandemic is characterized by infection cases that erupt in clusters and are not equally distributed within a nation. This means that suddenly depleted resources in some areas need to be augmented by complementary means secured from other areas: For example, to alleviate some of the pressure on regional parts of the French and Italian healthcare system, a number of intensive care patients have been transported from France or Italy to hospitals in Germany and Switzerland (Bateman, 2020).

These efforts to cope with a new global problem, whose nature we are still seeking to grasp, are not just about innovating to avoid harm and do good but also about creating effective governance systems that make agile and reflexive responses possible. Despite optimistic assessments of crisis response capabilities-for example, for countries such as the United States, the United Kingdom and the Netherlands (Cameron et al., 2019) - the current crisis reveals that public health care systems are still inadequate in anticipating rapid-response resources and establishing cross-sector and cross-border governance collaborations to communicate and deploy these resources effectively. Therefore, responsible innovation frameworks should enable us to account for post-normal innovation, or innovation produced by post-normal science - which is characterized by uncertainty, contested values, high stakes, and the need for urgent decisions (Funtowicz \& Ravetz, 1990). They should also enable us to observe, understand, explain, and show how our governance structures are changing, with new forms of governance 
and new ways of social and economic life emerging out of necessity (Baker, 2020). Such swift changes in governance can also be problematic, as citizens may see their individual freedom curtailed by the introduction of new regulations- e.g., legislation that allows detection of the location of persons via their mobile phones (Fussell, 2020) or for government to rule by decree instead of submitting to parliament for democratic scrutiny of new regulations (Hopkins, 2020). We highlight in the following what reflexive governance implies for corporations, thereby also reflecting back on responsible (corporate) innovation in light of COVID-19.

\section{CAPACITIES FOR REFLEXIVE AND PARTICIPATIVE CORPORATE GOVERNANCE: \\ TOWARD FUTURE RESEARCH AND PRACTICAL IMPLICATIONS}

Corporate governance can be adapted to provide a company with the capacities that allow for reflexivity and drawing on various forms of participation. Such innovative elements of corporate governance can be introduced in various areas. We focus on six core corporate governance areas: ownership structure, accountability of management, legal statute of the corporation, stakeholder participation, modes of decision making, and resource allocation (see summary in Table 3). Next we discuss these in more detail and provide questions that could guide future research.

Insert Table 3 about here

\section{Ownership or Shareholders Structure}

The ownership or shareholders structure could be adapted to reflect ownership that is based on long-term focused investors with social interests. Such impact investing is becoming more prominent, and investors see revenue opportunities therein (Dumas \& Louche, 2016;

Höchstädter \& Scheck, 2015). Changing the ownership structure in that way would foster the involvement of investors with a focus on "doing good," and the focus on long-term 
investments would require planning for sustainable development. It should therefore lead to increased reflexivity among shareholders and between shareholders and management about the goals of innovation and its contribution to sustainable development. Future research could investigate the link between governance structures that make long-term investing mandatory (e.g., holding shares for at least three or five years) and require a certain percentage of shares to be held by socially responsible investors and responsible innovation.

\section{Accountability of Management}

One possibility to ensure the accountability of management toward broader societal interests could be monitoring and, finally, rewarding the firm's impact on society alongside the triple bottom line of economic, social, and environmental performance (Elkington, 1998). This could be achieved by introducing mandatory reporting on social and environmental performance. While voluntary CSR reporting is already widespread, at least among multinational corporations (see, e.g., the number of companies submitting CSR reports according to the standard of the Global Reporting Initiative ${ }^{5}$ ), and governmental regulation especially in Europe makes it increasingly mandatory, a truly integrated reporting combining all three performance dimensions is still rare. Moreover, there exists no requirement to measure social and environmental impacts. However, measuring the impacts would show the extent to which the company contributes to sustainable development.

Many of the key performance indicators of CSR reports reflect the problems posed by grand societal challenges. Reporting also creates transparency and thereby invites stakeholder dialogue on future directions of the corporation, and thus its innovations. It would be interesting to investigate whether integrated reporting that requires reporting on real numbers of a firm's social and environmental impact would increase stakeholder participation and, ultimately, help to secure the legitimacy for innovation. Future research could also investigate

\footnotetext{
${ }^{5}$ www.globalreporting.org
} 
the links between the remuneration of top management that is tied to the triple-bottom-line performance of the firm, managerial reflexivity, and responsible innovation.

\section{Legal Statute of the Corporation}

From the concepts of the "profit with purpose" and the "purpose-driven" corporation, legal statutes that tie the corporation to a social purpose have begun to emerge (Hiller, 2013; Levillain, Segrestin, \& Filatotchev, 2017). It began in the United States with benefit corporation statutes in a number of states but diversified into various legal statutes, and now other countries are considering the introduction of similar forms as well, among them France, the United Kingdom, and Brazil (Levillain et al., 2017). Purpose-driven corporations are a specific form of for-profit social enterprise that through the legal statute allows managers to dedicate organizational resources to the purpose without compromising their fiduciary duty to shareholders.

It would be interesting to see how far these companies that make managers accountable not only for economic prosperity but also for achieving a social purpose redirect investments toward innovations that specifically do good, and thus ultimately contribute to mitigating grand challenges. Moreover, future research could try to examine the challenges that managers in these companies face and the conditions under which these companies facilitate innovations that avoid harm and do good most effectively and efficiently. Especially promising would be research on purpose-driven corporations and their innovations in countries that newly introduce these legal statutes.

\section{Stakeholder Participation}

Stakeholder participation could be guaranteed in various ways, accounting also for the tension between the involvement of expertise in generating ideas and broad societal support to facilitate idea implementation. More recent models of corporate governance based on stakeholder involvement and stewardship have been put forward (Filatotchev \& Nakajima, 2014; Scherer, Baumann-Pauly, \& Schneider, 2013). According to such models, corporations 
can, for instance, appoint outside directors or include stakeholders in the composition of the board of directors to open corporate governance to external opinions. Scherer, BaumannPauly, and Schneider (2013) cited the example of Lafarge, a French-based multinational producer of building materials, where the leadership decided to institutionalize its stakeholder relations by forming a stakeholder panel. ${ }^{6}$ This panel became part of the company's official corporate governance. It consisted of ten "critical friends" (Scherer, Baumann-Pauly, \& Schneider, 2013, p. 500) of Lafarge and met biannually with the executive committee and the CEO. Preparatory meetings with the World Wildlife Federation (WWF) took place throughout the year. Such stakeholder involvement could increase the reflexivity on innovations early on in the process and help to make the innovation process more responsible. In this regard, future research could evaluate how far stakeholder involvement that provides access to experts in social and environmental questions can foster such reflexivity on the goals and means of innovation and its contribution to sustainable development.

To secure the social acceptance of innovation, and thereby minimize harm, a broaderbased societal discourse would be required, especially in the implementation phase of innovation. Stilgoe et al. (2013) suggested a number of techniques for stakeholder inclusion to secure the acceptance of innovation; among these are citizens' juries and panels, focus groups, and deliberative mapping or polling, but also the possibility of involving stakeholders early on through open innovation. Their framework for responsible innovation was applied to a large geoengineering project in the United Kingdom that tested new technology with the aim of investigating "whether the purposeful injection of large quantities of particles into the stratosphere could ... provide a possible means to mitigate global warming" (Stilgoe et al., 2013, p. 1574). Cuppen and colleagues (Cuppen, 2012; Cuppen, Breukers, Hisschemöller, \& Bergsma, 2010) proposed a methodology to select stakeholders based on the diversity of

\footnotetext{
${ }^{6}$ In the meantime Lafarge was taken over by the Holcim corporation, and the original Lafarge stakeholder panel no longer exists.
} 
perspectives to ensure a constructive conflict in the Netherlands around energy options from biomass; constructive conflict "refers to an open exploration and evaluation of competing ideas and knowledge claims in order to achieve new ideas, insights and options for problem solving” (Cuppen, 2012, p. 26). Future research could investigate additional cases with varying approaches for stakeholder inclusion and their relation to the social acceptance of innovation and addressing grand challenges.

\section{Modes of Decision Making}

With regard to modes of decision making, voting could be geared toward consensus and agreement rather than majority voting when making decisions about investments in R\&D and innovation. Ideally, this would also include the participation of relevant stakeholders in the strategic decision making of the firm. An example of employee inclusion is the German Mitbestimmung (codetermination), which is mandatory by legal rules for corporations with more than 2000 employees and operates on various decision levels (Addison \& Schnabel, 2011): A representative of the employees is a member of the board of directors, while as many as half of the members of the supervisory board are delegated by the unions or worker representations. In addition, workers' councils are also included in various decision-making processes at the operational level of the firm. This seems an essential requirement for reflexive and participative governance and could guarantee a debate about the goals of innovation, as well as facilitating its social acceptance.

Research on deliberation has explored the conditions under which participation in decision making leads to positive effects with regard to defining goals and facilitating acceptance (Delli Carpini, Cook, \& Jacobs, 2004; Ryfe, 2005). Therefore, we suggest building on this research and encourage qualitative and quantitative empirical research to determine the conditions under which a system of codetermination by stakeholders can positively influence corporate innovations to avoid harm, do good, and contribute to sustainable development. For a positive effect of codetermination on innovation, see Kraft, 
Stank, and Dewenter (2011); there is even evidence for a positive effect of worker representation on firm value (see Fauver \& Fuerst, 2006).

In addition, we deem it relevant to study cases in which the codetermination did not help to prevent corporate fraud or address sustainability goals, as in the recent Volkswagen diesel scandal (Rhodes, 2016). We need to explore the shortcomings of this particular governance model, which in this case seems to have facilitated a collusion of interests among shareholders, management, workers, and state representatives. Obviously, in the VW case, codetermination did not include representatives of the environment or those most severely affected by the emissions. However, it included representatives of the state of Lower Saxonia, which owns $25 \%$ of Volkswagen shares. Future research could analyze the case in more detail, focusing for instance on the ambivalent role of government as shareholder.

Cooperatives provide organizational forms of codetermination that have been proven successful. British firm John Lewis is such a success story, where "Partners [i.e., employees] are legally empowered by the JLP Constitution to participate in a range of fora and media, which includes the Partnership Council, elected predominantly (80\%) by Partners, that is formally empowered to remove the Chairman and Chief Executive" (Paranque \& Willmott, 2014, p. 605). In France and Italy, cooperatives have become more popular in recent years (Corcoran \& Wilson, 2010).

More radical examples from Germany include "democratized" corporations (Dilk \& Littger, 2016). One example is the company Allsafe Jungfalk, specialized in securing cargo loads, which has already won the top prize as best employer four times (Dilk \& Littger, 2016). The company, for instance, allows its employees to vote on who is to take the lead. Another example is consulting firm Dark Horse, which established rules for meetings meant to facilitate agreement among participants. Decisions are made according to two principles: First, everyone is encouraged to voice her or his opinion; second, if there is no critical objection to a proposal and no counterproposal is offered, the suggestion is accepted (Dilk \& 
Littger, 2016). Again, we suggest that it requires empirical research to determine under which conditions which mode of decision making is most conducive to the goals of responsible innovation.

\section{Resource Allocation}

Finally, resources could be allocated by the organization to bottom-up socially innovative, entrepreneurial projects that specifically address grand challenges and contribute to sustainable development. The Boston Consulting Group (Beal, Dahl, Eisenmann, Nowack, \& Uekermann, 2017) listed current examples of multinational corporations supporting social entrepreneurship, among them a start-up that is a collaboration between Danone and the Grameen Bank called Grameen Danone. Its aim is to fight "child malnutrition in rural Bangladesh by producing fortified yogurt and distributing it to impoverished families through a network of 'Grameen ladies"' (Beal et al., 2017, pp. 2-3). BCG came to the conclusion that "Danone has benefited from leveraging its global R\&D function to support innovation within the social business" (Beal et al., 2017, p. 3). Providing such resources can facilitate polycentric structures for responsible innovations that contribute to sustainable development within an organization while maintaining a centralized strategy for R\&D.

Resource allocation decisions for responsible innovation also comprise investing resources in collaborations with actors beyond the firm's boundaries. As a case in point, research could study innovative responses to the COVID-19 pandemic involving collaborations between business firms and other actors, investigating for instance whether and how much reflexive corporate governance structures enable horizontal (business as part of cross-sector solutions) and vertical (from local to global) collaboration. Deliberative capacities can create slack resources for such innovations, e.g., through previously established stakeholder relations, intersections with the public sector and sensitivity to social acceptability of innovation, especially when contributing to the provision of public goods like health care. Deliberative governance creates the preconditions for perceiving potential trade-offs between 
the legitimacy, efficiency, and effectiveness of innovative solutions (as is often the case in responses to the COVID-19 pandemic), because deliberation creates the necessary sensitivity to stakeholder rights and related legitimacy questions, and enables the search for innovative solutions that try to take all three aspects into account; for example, as in the case of solutions relying on anonymous tracking of individuals to control the spread of the disease (Betschon, 2020).

Apart from researching specific aspects of reflexive and participative corporate governance, we propose that future research should also look more generally at the institutional environment, especially at the interplay between governmental regulation and corporate governance in responsible innovation. A useful approach could be the framework on varieties of institutional systems (Fainshmidt, Judge, Aguilera, \& Smith, 2018) because, compared to other approaches that study institutional differences (e.g., the varieties of capitalism or the national business systems approaches; see Hall \& Soskice, 2001; Whitley, 1999), it more specifically considers the role the state plays in the institutional environment and identifies institutional differences in countries that have been understudied to date (Fainshmidt et al., 2018). This might be promising for researching the effects of institutional differences on generating responsible innovation, especially when investigating cases in Africa, Asia, and Latin America. In general, we encourage future empirical research to investigate under what conditions which form or aspect of governance is conducive to producing innovations that avoid harm and do good and how this contributes to mitigating grand challenges.

\section{CONCLUSION}

Responsible governance involves establishing institutions, structures, and procedures on multiple levels to help resolve the grand challenges we have outlined by facilitating innovations that do not harm and, ideally, benefit society. We have argued that active participation in governance is key to ensuring the legitimacy, effectiveness, and efficiency of 
the processes and practices this involves. Stakeholder participation has both normative and pragmatic benefits for businesses and for society as a whole (see, e.g., Dryzek \& Pickering, 2017; Reed, 2008; Zammuto, 1984). Stakeholder participation in corporate governance, as a special type of governance, is normatively justified because it prevents the marginalization of certain groups and interests, facilitates the inclusion of those who are affected by political and economic decisions, increases trust, and empowers stakeholders to become active co-creators and to contribute their knowledge. Participation in governance is also pragmatically justified because it enhances the quality of the decisions that are made-decisions that rely on a broader knowledge base and range of perspectives and that take into account local sociocultural and environmental conditions tend to be better informed and balanced.

A key question with regard to participation is this: How and to what extent can or should stakeholders participate in governance, and on what level? General principles such as everyone should participate in matters of public concern are too abstract to serve as useful guidance (Fung, 2006). There are limits to participation based on individual, structural, and economic barriers: (1) Not everyone is willing and able to participate in collective decision making; (2) participation may be largely impeded by institutional obstacles, such as in fragile states that lack democratic institutions and actively exclude citizens from taking part in collective decisions; and (3) the cost of participation, deliberation, and consensus-building can be considerable and overstretch the available resources of corporations and of society as a whole (Irvin \& Stansbury, 2004; Kleinman, Delborne, \& Anderson, 2011; Sherlock, Kirk, \& Reeves, 2004).

Complex systems respond to these obstacles by making simultaneous use of multiple coordination mechanisms, such as markets, hierarchies, administration, and public deliberation. Additionally, they rely on representation and political or technical expertise to unburden their members of the task of engaging with any issue of public concern (Habermas, 1984). These coordination mechanisms cannot be replaced entirely by civic participation and 
deliberation. Instead, participation and deliberation should be treated as a necessary complement to the other coordination mechanisms. That means that we consider regulation by democratically elected governments still to be the most legitimate, effective, and efficient route to responsible innovation. However, there will often be a time lag between the discovery of harmful consequences of innovations and a regulatory response, and companies can avoid national regulation by relocating their value-creating activities to fragile states outside the reach of the democratic rule of law (note that almost two thirds of the world's states can be considered fragile; Fund for Peace, 2019). Therefore, we regard corporate governance as a necessary (but not the only) complement to governmental regulation.

The challenges posed by the COVID-19 pandemic raise the question of how to engage with the paradox that deliberative decisions often need to be made faster in an increasingly complex environment, whereas this complexity would require more time for adequate and socially legitimate decision making, because it requires actors to search for more information, engageme with potentially more stakeholders, weigh more complex facts, etc. One aspect future research might want to look into is the slack resources created by reflexive and participative governance structures that might be able to mitigate some of these challenges and might lead to better decisions also in the short run than decisions by nondeliberative or autocratic governance bodies.

We have discussed the limitations of prevailing corporate governance approaches with regard to innovations that address the grand challenges humanity is facing. To address these limitations, we have built on and extended the political CSR approach and argued that corporate governance requires reflexivity with regard to the tensions posed by responsible innovation - that is, business organizations need to be able to oscillate between participation and expertise, diversity and consensus, and polycentricity and centralization. Structures that allow for reflexivity and participation can help firms to acquire the capacities to do so and to produce legitimate, effective, and efficient innovations. Moreover, they allow firms to choose 
the relevant mode of engagement with stakeholders. The engagement of stakeholders through reflexive governance structures can help to define and achieve a consensus on the right goals for business innovation, provide the technical expertise to choose the most efficient means for reaching these goals, and make sure that the outcomes of innovation are accepted by the stakeholders. 


\section{REFERENCES}

Adams, R., Jeanrenaud, S., Bessard, J., Denyer, D., \& Overy, P. (2016). Sustainabilityoriented innovation: A systematic review. International Journal of Management Reviews, 18, 180-205.

Addison, J. T., \& Schnabel, C. (2011). Worker directors: A German product that did not export? Industrial Relations: A Journal of Economy and Society, 50(2), 354-374.

Agle, B. R., Mitchell, R. K., \& Sonnenfeld, J. A. (1999). Who matters to CEOs? An investigation of stakeholder attributes and salience, corporate performance, and CEO values. Academy of Management Journal, 42, 507-525.

Aguilera, R. V., Filatotchev, I., Gospel, H., \& Jackson, G. (2008). An organizational approach to comparative corporate governance: Costs, contingencies, and complementarities. Organization Science, 19(3), 475-492.

Aguilera, R. V., \& Jackson, G. (2003). The cross-national diversity of corporate governance: Dimensions and determinants. Academy of Management Review, 28, 447-465.

Aguilera, R. V., \& Jackson, G. (2010). Comparative and international corporate governance. Academy of Management Annals, 4(1), 485-556.

Andriopoulos, C., \& Lewis, M. W. (2009). Exploitation-exploration tensions and organizational ambidexterity: Managing paradoxes of innovation. Organization Science, 20(4), 696-717.

Argyris, C. (1977). Double loop learning in organizations. Harvard Business Review, 55(5), $115-125$.

Baker, P. C. (2020). 'We can't go back to normal': how will coronavirus change the world? The Guardian, 31 March 2020.

https://www.theguardian.com/world/2020/mar/31/how-will-the-world-emerge-fromthe-coronavirus-crisis (accessed 2 April 2020). 
Banerjee, S. B. (2007). Corporate social responsibility: The good, the bad and the ugly. Cheltenham, UK: Edward Elgar.

Bansal, P. (2005). Evolving sustainably: A longitudinal study of corporate sustainable development. Strategic Management Journal, 26(3), 197-218.

Bateman, J. (2020). 'Solidarity knows no borders': Germany treating dozens of coronavirus patients from Italy and France. The Independent, 1 April 2020. https://www.independent.co.uk/news/world/europe/coronavirus-germany-italy-francehospital-treatment-covid-19-a9440906.html (accessed 2 April 2020).

Baumann-Pauly, D., \& Scherer, A. G. (2013). The organizational implementation of corporate citizenship: An assessment tool and its application at UN Global Compact participants. Journal of Business Ethics, 117, 1-17.

Bazerman, M. H., \& Tenbrunsel, A. E. (2011). Ethical breakdowns: Good people often let back things happen. Why? Harvard Business Review, April, 58-65.

Beal, D., Dahl, F., Eisenmann, S., Nowack, D., \& Uekermann, F. (2017). Designing a social business that benefits the core. Retrieved from https://www.bcg.com/publications/2017/innovation-strategy-business-social-sectordesigning-social-business-benefits-core.aspx

Bebchuk, L. A., \& Weisbach, M. S. (2010). The state of corporate governance research. Review of Financial Studies, 23, 939-961.

Beck, U. (1992). Risk society: Towards a new modernity. London: Sage.

Bénabou, R., \& Tirole, J. (2010). Individual and corporate social responsibility. Economica, $77,1-19$.

Besley, T., \& Ghatak, M. (2007). Retailing public goods: The economics of corporate social responsibility. Journal of Public Economics, 91, 1045-1063. 
Betschon, S. (2020). Smartphone-Apps heften sich dem Coronavirus an die Fersen. Freiwillige Programmierer haben am Wochenende in Zürich Software entwickelt, die Kontakte mit infizierten Menschen nachzeichnen kann. Und dabei nicht die Privatsphäre der Betroffenen verletzt. Neue Zürcher Zeitung, 1 April 2020. https://www.nzz.ch/technologie/coronavirus-schweizer-apps-sollen-infektionen-

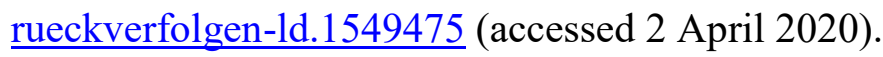

Blair, M. M. (1995). Ownership and control: Rethinking corporate governance in the twentyfirst century. Washington, DC: Brookings Institution Press.

Blair, M. M., \& Stout, L. A. (1999). A team production theory of corporate law. Journal of Corporation Law, 24, 751-806.

Blair, M. M., \& Stout, L. A. (2001). Corporate accountability: Director accountability and the mediating role of the corporate board. Washington University Law Quarterly, 79, 403447.

Bräuer, S. (2020). Handydaten: Überwachung des BAG wirft Fragen auf. Das Bundesamt für Gesundheit nutzt Handydaten, um zu überprüfen, wie viele Menschen sich im öffentlichen Raum aufhalten. Das ist aus datenschutzrechtlicher Sicht beunruhigend. Neue Zürcher Zeitung am Sonntag, 28 March 2020. https://nzzas.nzz.ch/schweiz/dasbag-nutzt-handydaten-zur-ueberwachung-das-wirft-fragen-auf1d.1549052?reduced=true (accessed 2 April 2020).

Brès, L., Raufflet, E., \& Boghossian, J. (2018). Pluralism in organizations: Learning from unconventional forms of organizations. International Journal of Management Reviews, 20, 364-386.

Cadbury, A. (2003). Foreword. In Corporate governance and development (pp. v-vii). Washington, DC: Global Corporate Governance Forum. 
Cagnin, C., Amanatidou, E., \& Keenan, M. (2012). Orienting European innovation systems towards grand challenges and the roles that FTA can play. Science and Public Policy, 39, 140-152.

Cameron, E. E., Nuzzo, J. B., \& Bell, J. A. (2019). Global Health Security Index: Building collective action and accountability. Nuclear Threat Initiative, Johns Hopkins Center for Health Security \& The Economist Intelligence Unit. Available at: https://www.ghsindex.org/wp-content/uploads/2019/10/2019-Global-Health-Security$\underline{\text { Index.pdf }}$

Chambers, S. (2003). Deliberative democratic theory. Annual Review of Political Science, 6, $307-326$.

Claessens, S., \& Yurtoglu, B. (2012). Corporate governance and development-An update. Washington, DC: International Finance Corporation.

Corcoran, H., \& Wilson, D. (2010). The worker co-operative movements in Italy, Mondragon and France: Context, success factors and lessons. Calgary, Alberta: Canadian Worker Cooperative Federation.

Crane, A., Palazzo, G., Spence, L., \& Matten, D. (2014). Contesting the value of "shared value." California Management Review, 56, 130-148.

Cuppen, E. (2012). Diversity and constructive conflict in stakeholder dialogue: Considerations for design and methods. Policy Sciences, 45(1), 23-46.

Cuppen, E., Breukers, S., Hisschemöller, M., \& Bergsma, E. (2010). Q methodology to select participants for a stakeholder dialogue on energy options from biomass in the Netherlands. Ecological Economics, 69(3), 579-591.

Deci, E. L., Koestner, R., \& Ryan, R. M. (1999). A meta-analytic review of experiments examining the effects of extrinsic rewards on intrinsic motivation. Psychological Bulletin, 125(6), 627-668. 
Delli Carpini, M. X., Cook, F. L., \& Jacobs, L. R. (2004). Public deliberation, discursive participation, and citizen engagement. A review of the empirical literature. Annual Review of Political Science, 7, 315-344.

Deschamps, J.-P. (2012). What is innovation governance? Lausanne, Switzerland: International Institute for Management Development (IMD).

Dilk, A., \& Littger, H. (2016). We are boss [Wir sind Chef]. Enorm, March/April, 16-29.

Donaldson, T., \& Preston, L. E. (1995). The stakeholder theory of the corporation: Concepts, evidence, and implications. Academy of Management Review, 20(1), 65-91.

Driver, C., \& Thompson, G. (2002). Corporate governance and democracy: The stakeholder debate revisited. Journal of Management and Governance, 6, 111-130.

Drucker P. F. (1974). Management: Tasks, responsibilities, practices. London: Heinemann.

Dryzek, J. S. (1990). Discursive democracy: Politics, policy, and political science. Cambridge, UK: Cambridge University Press.

Dryzek, J. S., \& Pickering, J. (2017). Deliberation as catalyst for reflexive environmental governance. Ecological Economics, 131, 353-380.

Dumas, C., \& Louche, C. (2016). Collective beliefs on responsible investment. Business \& Society, 55(3), 427-457.

Eberl, P., Geiger, D., \& Aßländer, M. S. (2015). Repairing trust in an organization after integrity violations: The ambivalence of organizational rule adjustments. Organization Studies, 36, 1205-1235.

EDANA (2020). COVID-19 and the nonwovens industry. Available at: https://www.edana.org/how-we-take-action/covid-19 (accessed 2 April 2020).

Elkington, J. (1998). Cannibals with forks: The triple bottom line of the 21st century business. Oxford, UK: Capstone Publishing Ltd. 
Elster, J. (1986). The market and the forum: Three varieties of political theory. In J. Elster \& A. Hylland (Eds.), Foundations of social choice theory (pp. 103-132). Cambridge, UK: Cambridge University Press.

European Commission. (2008). Challenging Europe's research: Rationales for the European research area. Brussels: Author. Retrieved from https://pdfs.semanticscholar.org/848d/b78aa6b1464b5eafd1f743c7ad4a4fb5e1d1.pdf? $\_\mathrm{ga}=2.238705865 .831323509 .1582601007-1972545791.1582601007$

Fainshmidt, S., Judge, W. Q., Aguilera, R. V., \& Smith, A. (2018). Varieties of institutional systems: A contextual taxonomy of understudied countries. Journal of World Business, 53, 307-322.

Fast, S. (2013). A Habermasian analysis of local renewable energy deliberations. Journal of Rural Studies, 30, 86-98.

Fauver, L., \& Fuerst, M. E. (2006). Does good corporate governance include employee representation? Evidence from German corporate boards. Journal of Financial Economics, 82, 673-710.

Ferraro, F., Etzion, D., \& Gehman, J. (2015). Tackling grand challenges pragmatically: Robust action revisited. Organization Studies, 36, 363-390.

Filatotchev, I., \& Nakajima, C. (2014). Corporate governance, responsible managerial behavior, and corporate social responsibility: Organizational efficiency versus organizational legitimacy? Academy of Management Perspectives, 28(3), 289-306.

Fleming, P., \& Jones, M. T. (2013). The end of corporate responsibility: Crisis and Critique. Thousand Oaks, CA: Sage.

Folke, C., Hahn, T., Olsson, P., \& Norberg, J. (2005). Adaptive governance of socialecological systems. Annual Review of Environment and Resources, 30, 441-473.

Fottrell, Q. (2020). 'You can never make things perfectly safe with zero risk.' How can you choose between saving the U.S. economy and saving lives? MarketWatch, 29 March 
2020, https://www.marketwatch.com/story/how-do-you-choose-between-economicdeaths-of-despair-and-coronavirus-victims-economists-lawmakers-grapple-with-amoral-conundrum-2020-03-26 (accessed 29 March 2020).

Freeman, R. E. (1984). Strategic management: A stakeholder approach. Boston: Pitman.

Frey, B. S., \& Jegen, R. (2001). Motivation crowding theory. Journal of Economic Surveys, $15,589-611$.

Frey, B. S., \& Osterloh, M. (2005). Yes, managers should be paid like bureaucrats. Journal of Management Inquiry, 14, 96-111.

Friedman, M. (1970, September 13). The social responsibility of business is to increase its profits. New York Times Magazine. Retrieved from https://graphics8.nytimes.com/packages/pdf/business/miltonfriedman1970.pdf

Friedman, U. (2020). The Coronavirus-denial movement now has a leader. Brazilian president Jair Bolsonaro has lashed out against local officials who have implemented severe lockdowns, accusing them of destroying the country. The Atlantic, 27 March 2020, https://www.theatlantic.com/politics/archive/2020/03/bolsonaro-coronavirus-denialbrazil-trump/608926/ (accessed 31 March, 2020).

Fund for Peace. (2019). Fragile States Index 2019. Washington, DC: Author.

Fung, A. (2003a). Recipes for public spheres: Eight institutional design choices and their consequences. Journal of Political Philosophy, 11, 338-367.

Fung, A. (2003b). Deliberative democracy and international labor standards. Governance, 16, $51-71$.

Fung, A. (2006). Varieties of participation in complex governance. Public Administration Review, 66 (December), 66-75.

Funtowicz, S. O., \& Ravetz, J. R. (1990). Uncertainty and quality in science for policy (vol. 15). Berlin: Springer Science \& Business Media. 
Fussell, S. (2020). The Coronavirus Relief Bill promotes surveillance for health. The package includes $\$ 500$ million for tracking and data collection, worrying some government watchdogs. Wired, 31 March 2020. https://www.wired.com/story/coronavirus-reliefbill-promotes-surveillance-health/ (accessed 2 April 2020).

Fuster, A., \& Meier, S. (2010). Another hidden cost of incentives: The detrimental effect on norm enforcement. Management Science, 56, 57-70.

Galaz, V., Crona, B., Österblom, H., Olsson, P., \& Folke, C. (2012). Polycentric systems and interacting planetary boundaries: Emerging governance of climate change-ocean acidification-marine biodiversity. Ecological Economics, 81, 21-32.

George, G., Howard-Grenville, J., Joshi, A., \& Tohanyi, L. (2016). Understanding and tackling societal grand challenges through management research. Academy of Management Journal, 59, 1880-1895.

Gomez, P.-Y., \& Korine, H. (2008). Entrepreneurs and democracy: A political theory of corporate governance. Cambridge, UK: Cambridge University Press.

Grand Challenges Canada. (2011, January). The grand challenges approach. Toronto: McLaughlin-Ritman Centre for Global Health.

Greve, H. R., Palmer, D., \& Pozner, J.-E. (2010). Organizations gone wild: The causes, processes, and consequences of organizational misconduct. Academy of Management Annals, 4, 53-107.

Griggs, D., et al. (2013). Policy: Sustainable development goals for people and planet. Nature, 495(7441), 305-307.

Grinbaum, A., \& Groves, C. (2013). What is "responsible" about responsible innovation? Understanding the ethical issues. In R. Owen, J. Bessant, \& M. Heintz (Eds.), Responsible innovation: Managing the responsible emergence of science and innovation in society (pp. 119-142). Chichester, UK: Wiley. 
Gupta, J. (2016). Climate change governance: History, future, and triple-loop learning? Wiley Interdisciplinary Reviews: Climate Change, 7, 192-210.

Habermas, J. (1984). The theory of communicative action: Reason and the rationalization of society (Vol. 1). Boston: Beacon Press.

Habermas, J. (1998). Between facts and norms: Contributions to a discourse theory of law and democracy. Cambridge, UK: Polity Press.

Habermas, J. (2001). The inclusion of the other: Studies in political theory. Cambridge, MA: MIT Press.

Hall, P. A., \& Soskice, D. (2001). Varieties of capitalism: The institutional foundations of comparative advantage. Oxford, UK: Oxford University Press.

Hambrick, D. C., Werder, A. v., \& Zajac, E. J. (2008). New directions in corporate governance research. Organization Science, 19, 381-385.

Hiller, J. S. (2013). The benefit corporation and corporate social responsibility. Journal of Business Ethics, 118(2), 287-301.

Höchstädter, A. K., \& Scheck, B. (2015). What's in a name: An analysis of impact investing understandings by academics and practitioners. Journal of Business Ethics, 132, 449475.

Hopkins, V. (2020). Orban handed power to rule by decree in Hungary. The Financial Times, 30 March 2020. https://www.ft.com/content/4dc85972-e917-4c8d-9db18e72400b9e8a (accessed 2 April 2020).

Hopwood, B., Mellor, M., \& O’Brien, G. (2005). Sustainable development: Mapping different approaches. Sustainable Development, 13(1), 38-52.

Irvin, R. A., \& Stansbury, J. (2004). Citizen participation in decision making: Is it worth the effort? Public Administration Review, 64, 55-65.

Jensen, M. J. (2002). Value maximization, stakeholder theory, and the corporate objective function. Business Ethics Quarterly, 12, 235-256. 
Jensen, M. J., \& Meckling, W. H. (1976). Theory of the firm: Managerial behavior, agency costs, and ownership structure. Journal of Financial Economics, 3, 305-360.

Jensen, M. J., \& Murphy, K. J. (1990). Performance pay and top-management incentives. Journal of Political Economy, 98, 225-264.

Jordan, A. (2008). The governance of sustainable development: Taking stock and looking forward. Environment and Planning C: Government and Policy, 26, 17-33.

Kaul, I., Conceicao, P., Le Goulven, K., \& Mendoza, R. U. (2003). Providing global public goods: Managing globalization. Oxford, UK: Oxford University Press.

Kerr, S. (1975). On the folly of rewarding A, while hoping for B. Academy of Management Journal, 18, 769-783.

Kleinman, D. L., Delborne, J. A., \& Anderson, A. A. (2011). Engaging citizens: The high cost of citizen participation in high technology. Public Understanding of Science, 20, 221240.

Kohn, A. (1993). Punished by rewards: The trouble with gold stars, incentive plans, A's, praise, and other bribes. Boston: Houghton Mifflin.

Kolk, A., \& Lenfant, F. (2015). Partnerships for peace and development in fragile states: Identifying missing links. Academy of Management Perspectives, 29, 422-437.

Kraft, K., Stank, J., \& Dewenter, R. (2011). Co-determination and innovation. Cambridge Journal of Economics, 35, 145-172.

Kuras, P. (2020). No, Matt Hancock: biotech giants are not behind Germany's coronavirus success. The Guardian, 6 April 2020. https://www.theguardian.com/commentisfree/2020/apr/06/matt-hancock-biotechgermany-coronavirus-health-system (accessed 6 April 2020).

Laufer, W. S. (2003). Social accountability and corporate greenwashing. Journal of Business Ethics, 43, 253- 261. 
Lazonik, W., \& M. O’Sullivan (2000). Maximizing shareholder value: A new ideology of corporate governance. Economy and Society, 29(1), 13-35.

Lee, R. G., \& Petts, J. (2013). Adaptive governance for responsible innovation. In R. Owen, J. Bessant, \& M. Heintz (Eds.), Responsible innovation: Managing the responsible emergence of science and innovation in society (pp. 143-164). Chichester, UK: Wiley.

Letza, S., Sun, X., \& Kirkbride, J. (2004). Shareholding versus stakeholding: A critical review of corporate governance. Corporate Governance, 12, 242-262.

Levillain, K., Segrestin, B., \& Filatotchev, I. (2017). New forms of governance and profitwith-purpose companies. Introduction to the 1st research workshop. Paris: Mines ParisTech.

Levin, K., Cashore, B., Bernstein, S., \& Auld, G. (2012). Overcoming the tragedy of super wicked problems: Constraining our future selves to ameliorate global climate change. Policy Science, 45, 123-152.

Levy, D., \& Kolk, A. (2002). Strategic responses to global climate change: Conflicting pressures on multinationals in the oil industry. Business and Politics, 4(3), 275-300.

Lidskog, R., \& Elander, I. (2010). Addressing climate change democratically. Multi-level governance, transnational networks and governmental structures. Sustainable Development, 18, 32-41.

Luke, T. W. (2011). Environmentality. In J. S. Dryzek, R. B. Norgaard, \& D. Schlosberg (Eds.), The Oxford handbook of climate change and society (pp. 96-109). Oxford, UK: Oxford University Press.

March, J. G. (1991). Exploration and exploitation in organizational learning. Organization Science, 2(1), 71-87.

Marcus, A. A., \& Fremeth, A. R. (2009). Green management matters regardless. Academy of Management Perspectives, 23 (3), 17-26. 
Marti, E., \& Scherer, A. G. (2016). Financial regulation and social welfare: The critical contribution of management theory. Academy of Management Review, 41(2), 298323.

Matten, D., \& Crane, A. (2005). Corporate citizenship: Toward an extended theoretical conceptualization. Academy of Management Review, 30(1), 166-179.

McGuire, C. J. (2017). Uncommunicating climate change in the Trump era: Influencing public policy by attempting to control the message. Environmental Justice, 10(6), $209-212$.

Meadowcroft, J., \& Steurer, R. (2013). Assessment practices in the policy and politics cycles: A contribution to reflexive governance for sustainable development? Journal of Environmental Policy and Planning, 1-23.

Mena, S., \& Palazzo, G. (2012). Input and output legitimacy of multistakeholder initiatives. Business Ethics Quarterly, 22, 527-556.

Michaels, R. (2009). Global legal pluralism. Annual Review of Law and Social Science, 5(1), 243-262.

Mintzberg, H., \& Westley, F. (2001). Decision making: It's not what you think. MIT Sloan Management Review, Spring, 89-93.

Mitchell, R. K., Agle, B. R., \& Wood, D. J. (1997). Toward a theory of stakeholder identification and salience: Defining the principle of who and what really counts. Academy of Management Review, 22, 853-886.

Mitchell, R. K., Weaver, G. R., Agle, B. R., Bailey, A. D., \& Carlson, J. (2016). Stakeholder agency and social welfare: Pluralism and decision making in the multi-objective corporation. Academy of Management Review, 41, 252-275.

Mulgan, G. (2006). The process of social innovation. Innovations, 1(2), 145-162.

Naudé, W., Santos-Paulino, A. U., \& McGillivray, M. (2011). Fragile states: Causes, costs, and responses. Oxford, UK: Oxford University Press. 
Nilsson, A. (2017). Making norms to tackle global challenges: The role of intergovernmental organizations. Research Policy, 46, 171-181.

OECD. (2011). Fostering innovation to address social challenges. Paris: OECD Publishing.

OECD. (2012). Meeting global challenges through better governance: International cooperation in science, technology and innovation. Paris: OECD Publishing.

Oliver, C. (1991). Strategic responses to institutional processes. Academy of Management Review, 16, 145-170.

Oltermann, P. (2020). Germany's devolved logic is helping to win the coronavirus race. With 400 public health offices forging ahead with testing, the county is a model for others to emulate. The Guardian, 5 April 2020. https:/www.theguardian.com/world/2020/apr/05/germanys-devolved-logic-is-helpingit-win-the-coronavirus-race?CMP=Share_iOSApp_Other (accessed 5 April 2020).

Owen, R., Stilgoe, J., Macnaghten, P., Gorman, M., Fisher, E., \& Guston, D. (2013). A framework for responsible innovation. In R. Owen, J., Bessant, \& M. Heintz (Eds.), Responsible innovation: Managing the responsible emergence of science and innovation in society (pp. 27-50). Chichester, UK: Wiley.

Pache, A.-C., \& Santos, F. (2010). When worlds collide: The internal dynamics of organizational responses to conflicting institutional demands. Academy of Management Review, 35, 455-476.

Palazzo, G., \& Scherer, A. G. (2006). Corporate legitimacy as deliberation. A communicative framework. Journal of Business Ethics, 66, 71-88.

Palazzo, G., \& Scherer, A. G. (2010). The United Nations Global Compact as a learning approach. In A. Rasche \& G. Kell (Eds.), The United Nations Global Compact: Achievements, trends and challenges (pp. 234-247). Cambridge, UK: Cambridge University Press. 
Paranque, B., \& Willmott, H. (2014). Cooperatives—saviours or gravediggers of capitalism? Critical performativity and the John Lewis Partnership. Organization, 21, 604-625.

Parker, C. (2002). The open corporation: Effective self-regulation and democracy. New York: Cambridge University Press.

Phillips, R. (2003). Stakeholder legitimacy. Business Ethics Quarterly, 13, 25-41.

Porter, M. E., \& Kramer, M. R. (2011). Creating shared value. Harvard Business Review, January-February, 62-77.

Portes, J. (2020). Don't believe the myth that we must sacrifice lives to save the economy. The Guardian, 25 March 2020, https://www.theguardian.com/commentisfree/2020/mar/25/there-is-no-trade-offbetween-the-economy-and-health (accessed 29 March 2020).

Rämö, H. (2002). Doing things right and doing the right things. Time and timing in projects. International Journal of Project Management, 20, 569-574.

Rasche, A., Waddock, S., \& McIntosh, M. (2013). The United Nations Global Compact: Retrospect and prospect. Business \& Society, 52, 6-30.

Rauwald, C. \& Loh, T. (2020). New virus test shortens wait to 2.5 hours from two days. Bloomberg, 26 March 2020. https://www.bloomberg.com/news/articles/2020-0326/bosch-develops-fast-virus-tests-to-shorten-wait-for-answers (accessed 2 April 2020).

Reed, M. S. (2008). Stakeholder participation for environmental management: A literature review. Biological Conservation, 141, 2417-2431.

Reid, W. V. et al. (2010). Earth system science for global sustainability: Grand challenges. Science, 330(6006), 916-917.

Reid, E. M., \& Toffel, M. W. (2009). Responding to public and private politics: Corporate disclosure of climate change strategies. Strategic Management Journal, 30(11), 11571178. 
Responsible Industry Consortium. (2018). Responsible industry: Benefits of responsible research and innovation in ICT for an ageing society. Retrieved from $\underline{\text { www.responsible-industry.eu }}$

Rhodes, C. (2016). Democratic business ethics: Volkswagen's emissions scandal and the disruption of corporate sovereignty. Organization Studies, 37, 1501-1518.

Richards, N. M. (2013). The dangers of surveillance. Harvard Law Review, 126, 1934-1965.

Rittel, H. W. J., \& Webber, M. M. (1973). Dilemmas in a general theory of planning. Policy Sciences, 4, 155-169.

Roberts, N. (2004). Public deliberation in an age of direct citizen participation. American Review of Public Administration, 34, 315-353.

Roche (2020). Roche's cobas SARS-CoV-2 Test to detect novel coronavirus receives FDA Emergency Use Authorization and is available in markets accepting the CE mark. https://www.roche.com/media/releases/med-cor-2020-03-13.htm (accessed 2 April 2020).

Rockström, J., et al. (2009). A safe operating space for humanity. Nature, 461(7263), 472475.

Ryfe, D. M. (2005). Does deliberative democracy work? Annual Review of Political Science, $8,49-71$.

Schembera, S., \& Scherer, A. G. (2017). Organizational strategies in the context of legitimacy loss: Radical versus gradual responses to disclosed corruption. Strategic Organization, 15(3), 301-337.

Scherer, A. G. (2015). Can hypernorms be justified? Insights from a discourse-ethical perspective. Business Ethics Quarterly, 25(4), 489-516.

Scherer, A. G. (2018). Theory assessment and agenda setting in political CSR: A critical theory perspective. International Journal of Management Reviews, 20, 387-410. 
Scherer, A. G., Baumann-Pauly, D., \& Schneider, A. (2013). Democratizing corporate governance: Compensating for the democratic deficit of corporate political activity and corporate citizenship. Business \& Society, 52, 473-514.

Scherer, A. G., \& Palazzo, G. (2007). Toward a political conception of corporate social responsibility: Business and society seen from a Habermasian perspective. Academy of Management Review, 32, 1096-1120.

Scherer, A. G., \& Palazzo, G. (2011). The new political role of business in a globalized world: A review of a new perspective on CSR and its implications for the firm, governance, and democracy. Journal of Management Studies, 48, 899-931.

Scherer, A. G., Palazzo, G., \& Matten, D. (2009). Globalization as a challenge for business responsibilities. Business Ethics Quarterly, 19(3), 327-347.

Scherer, A. G., Palazzo, G., \& Seidl, D. (2013). Managing legitimacy in complex and heterogeneous environments: Sustainable development in a globalized world. Journal of Management Studies, 50, 259-284.

Scherer, A. G., Rasche, A., Palazzo, G., \& Spicer, A. (2016). Managing for political corporate social responsibility: New challenges and directions for PCSR 2.0. Journal of Management Studies, 53(3), 273-298.

Schneider, A., \& Scherer, A. G. (2015). Corporate governance in a risk society. Journal of Business Ethics, 126, 309-323.

Schouten, G., Leroy, P., \& Glasbergen, P. (2012). On the deliberative capacity of private multi-stakeholder governance: The roundtables on responsible soy and sustainable palm oil. Ecological Economics, 83, 42-50.

Sethi, P., \& Schepers, D. (2013). United Nations Global Compact: The promise-performance gap. Journal of Business Ethics, 122, 193-208. 
Sherlock, K. L., Kirk, E. A., \& Reeves, A. D. (2004). Just the usual suspects? Partnerships and environmental regulation. Environment and Planning C: Government and Policy, $22,651-666$.

Shleifer, A., \& Vishny, R. W. (1997). A survey of corporate governance. Journal of Finance, 52(2), 737-783.

Siegel, D. S. (2009). Green management matters only if it yields more green: An economic/strategic perspective. Academy of Management Perspectives, 23(3), 5-16.

Smith, W. K., \& Lewis, M. W. (2011). Toward a theory of paradox: A dynamic equilibrium model of organizing. Academy of Management Review, 36(2), 381-403.

Sorensen, E., \& Torfing, J. (2009). Making governance networks effective and democratic through metagovernance. Public Administration, 87, 234-258.

Spar, D. L., \& La Mure, L. T. (2003). The power of activism: Assessing the impact of NGOs on global business. California Management Review, 45, 78-101.

Stahl, B. C. (2018). Business and industry towards a responsible innovation: The example of ICT in ageing. Retrieved from https://blog.rri-tools.eu/-/business-and-industrytowards-a-responsible-innovation-the-example-of-ict-in-ageing

Stahl, G. K., \& Sully de Luque, M. (2014). Antecedents of responsible leader behavior: A research synthesis, conceptual framework, and agenda for future research. Academy of Management Perspectives, 28, 235-254.

Stilgoe, J., Owen, R., \& Macnaghten, P. (2013). Developing a framework for responsible innovation. Research Policy, 42, 1568-1580.

Stone, C. D. (1975). Where the law ends. New York: Harper \& Row.

Suchman, M. C. (1995). Managing legitimacy: Strategic and institutional approaches. Academy of Management Review, 20(3), 571-610.

Sundaram, A. K., \& Inkpen, A. C. (2004). The corporate objective revisited. Organization Science, 15, 350-363. 
Swyngedouw, E. (2006). Governance innovation and the citizen: The Janus face of governance-beyond-the-state. Urban Studies, 42(11), 1191-2006.

Tetrault Sirsly, C.-A., \& Lamertz, K. (2008). When does a corporate social responsibility initiative provide a first-mover advantage? Business \& Society, 47(3), 343-369.

Teubner, G., \& Korth, O. (2012). Two kinds of legal pluralism: Collision of transnational regimes in the double fragmentation of world society. In M. Young (Ed.), Regime interaction in international law: Facing fragmentation (pp. 23-54). Oxford, UK: Oxford University Press.

Thompson, D. F. (2008). Deliberative democratic theory and empirical political science. Annual Review of Political Science, 11, 497-520.

Thompson, V. A. (1965). Bureaucracy and innovation. Administrative Science Quarterly, 10, $1-20$.

Tosey, P., Visser, M., \& Saunders, M. N. K. (2012). The origins and conceptualizations of “triple-loop” learning: A critical review. Management Learning, 43, 291-307.

Taylor, D. B. (2020). A timeline of the Coronavirus Pandemic. The New York Times, 31 March 2020. https://www.nytimes.com/article/coronavirus-timeline.html (accessed 2 April 2020).

Ulrich, P. (2008). Integrative economic ethics. Cambridge, UK: Cambridge University Press.

UNCTAD. (2015). World investment report 2015: Reforming international investment governance. Geneva: United Nations.

United Nations. (1987). Report of the World Commission on Environment and Development. General Assembly Resolution 42/187. Retrieved from https://undocs.org/pdf?symbol=en/A/RES/42/187

United Nations. (2015). Transforming our world: The 2030 agenda for sustainable development. Resolution adopted by the General Assembly on 25 September 2015 (A/RES/70/1). New York: Author. 
Van den Hove, S. (2006). Between consensus and compromise: Acknowledging the negotiation dimension in participatory approaches. Land Use Policy, 23, 10-17.

Voegtlin, C., \& Pless, N. M. (2014). Global governance: CSR and the role of the UN Global Compact. Journal of Business Ethics, 122(2), 179-191.

Voegtlin, C., \& Scherer, A. G. (2017). Responsible innovation and the innovation of responsibility: Governing sustainable development in a globalized world. Journal of Business Ethics, 143, 227-243.

von Schomberg, R. (2011). Prospects for technology assessment in a framework of responsible research and innovation. In M. Dusseldorp \& R. Beecroft (Eds.), Technikfolgen Abschätzen Lehren: Bildungspotenziale transdisziplinärer Methoden, 39-62. Wiesbaden, Germany: Springer.

Voß, J.-P., Kemp, R., \& Bauknecht, D. (2006). Reflexive governance: A view on an emerging path. In J.-P. Voß, D. Bauknecht, \& R. Kemp (Eds.), Reflexive governance for sustainable development (pp. 419-437). Cheltenham, UK: Edward Elgar.

Waddock, S. (2008). Building a new institutional infrastructure for corporate responsibility. Academy of Management Perspectives, 22(3), 87-108.

Westphal, J. D., \& Zajac, E. J. (2013). A behavioral theory of corporate governance: Explicating the mechanisms of socially situated and socially constituted agency. Academy of Management Annals, 7, 607-661.

Whiteman, G., Walker, B., \& Perego, P. (2013). Planetary boundaries: Ecological foundations for corporate sustainability. Journal of Management Studies, 50, 307-336.

Whitley, R. (1999). Divergent capitalisms: The social structuring and change of business systems. Oxford, UK: Oxford University Press.

Williamson, O. E. (1985). The economic institutions of capitalism. New York: Free Press. Wiseman, R. M., \& Gomez-Mejia, L. R. (1998). A behavioral agency model of managerial risk taking. Academy of Management Review, 23, 133-153. 
WTO. (2015). World trade report 2015. Speeding up trade: Benefits and challenges of implementing the WTO Trade Facilitation Agreement. Geneva: Author.

Young, M. A. (Ed.). (2012). Regime interaction in international law: Facing fragmentation. Cambridge, UK: Cambridge University Press.

Zammuto, R. F. (1984). A comparison of multiple constituency models of organizational effectiveness. Academy of Management Review, 9, 606-616.

Zuboff, S. (2015). Big other: Surveillance capitalism and the prospects of an information civilization. Journal of Information Technology, 30, 75-89. 
TABLE 1. Corporate Governance Approaches and Their Link to Responsible Innovation

\begin{tabular}{|c|c|c|c|c|}
\hline & & $\begin{array}{l}\text { Shareholder value } \\
\text { approach }\end{array}$ & $\begin{array}{l}\text { Stakeholder } \\
\text { approach }\end{array}$ & Political CSR approach \\
\hline \multirow{3}{*}{\multicolumn{2}{|c|}{ Basic assumptions }} & $\begin{array}{l}\text { Principal-agency } \\
\text { theory }\end{array}$ & Stakeholder theory & Political CSR theory \\
\hline & & $\begin{array}{l}\text { Accountability of } \\
\text { management toward } \\
\text { owners/shareholders }\end{array}$ & $\begin{array}{l}\text { Accountability of } \\
\text { management toward } \\
\text { various stakeholders } \\
\text { of the firm }\end{array}$ & $\begin{array}{l}\text { Accountability of } \\
\text { management toward } \\
\text { society }\end{array}$ \\
\hline & & $\begin{array}{l}\text { Focus on maximizing } \\
\text { shareholder value }\end{array}$ & $\begin{array}{l}\text { Focus on multiple } \\
\text { objectives/triple } \\
\text { bottom line }\end{array}$ & $\begin{array}{l}\text { Focus on firm's } \\
\text { contribution to society }\end{array}$ \\
\hline \multicolumn{2}{|c|}{$\begin{array}{l}\text { Favorable conditions for } \\
\text { responsible innovation }\end{array}$} & $\begin{array}{l}\text { Contribution to } \\
\text { responsible } \\
\text { innovation when } \\
\text { government sets the } \\
\text { right incentives to } \\
\text { invest in new } \\
\text { products or processes } \\
\text { that avoid harm and } \\
\text { do good }\end{array}$ & $\begin{array}{l}\text { Contribution to } \\
\text { responsible innovation } \\
\text { when powerful } \\
\text { stakeholders have an } \\
\text { interest in new } \\
\text { products or processes } \\
\text { that avoid harm and do } \\
\text { good }\end{array}$ & $\begin{array}{l}\text { Contribution to } \\
\text { responsible innovation } \\
\text { when deliberation with } \\
\text { citizens who have an } \\
\text { interest in or contribute } \\
\text { knowledge to new } \\
\text { products or processes that } \\
\text { avoid harm and do good } \\
\text { is enabled }\end{array}$ \\
\hline \multirow[t]{3}{*}{$\begin{array}{l}\text { Limitations } \\
\text { with regard } \\
\text { to responsible } \\
\text { innovation }\end{array}$} & Legitimacy & $\begin{array}{l}\text { In cases of state } \\
\text { failure there is no } \\
\text { mechanism to ensure } \\
\text { the social acceptance } \\
\text { (legitimacy) of } \\
\text { innovation. }\end{array}$ & $\begin{array}{l}\text { No mechanism } \\
\text { specified to integrate } \\
\text { the heterogeneous } \\
\text { institutional and moral } \\
\text { concerns of the global } \\
\text { stakeholders to ensure } \\
\text { the social acceptance } \\
\text { (legitimacy) of } \\
\text { innovation. }\end{array}$ & $\begin{array}{l}\text { When there is no capacity } \\
\text { to deal with the } \\
\text { limitations of } \\
\text { deliberation, the } \\
\text { corporation either } \\
\text { remains stuck in the } \\
\text { hierarchical mode of } \\
\text { decision making that does } \\
\text { not guarantee the social } \\
\text { acceptance (legitimacy) } \\
\text { of innovation ... }\end{array}$ \\
\hline & \multirow[t]{2}{*}{$\begin{array}{l}\text { Effective- } \\
\text { ness and } \\
\text { efficiency }\end{array}$} & $\begin{array}{l}\text { When the state is } \\
\text { unwilling or unable to } \\
\text { provide the right } \\
\text { incentives, there is no } \\
\text { evaluation of the } \\
\text { goals (effectiveness) } \\
\text { and means } \\
\text { (efficiency) of } \\
\text { innovation. }\end{array}$ & $\begin{array}{l}\text { When powerful } \\
\text { stakeholders have no } \\
\text { interest in facilitating } \\
\text { sustainable } \\
\text { development, an } \\
\text { evaluation of the goals } \\
\text { (effectiveness) and } \\
\text { means (efficiency) of } \\
\text { innovation will be } \\
\text { difficult. }\end{array}$ & \multirow[t]{2}{*}{$\begin{array}{l}\text {... or cannot reach an } \\
\text { agreement with } \\
\text { stakeholders about the } \\
\text { goals (effectiveness) and } \\
\text { means (efficiency) of } \\
\text { innovation. }\end{array}$} \\
\hline & & $\begin{array}{l}\text { Especially limited in } \\
\text { a globalized business } \\
\text { environment and } \\
\text { when operating in } \\
\text { fragile or failed states }\end{array}$ & $\begin{array}{l}\text { No mechanism } \\
\text { specified to solve } \\
\text { conflicts of goals in } \\
\text { the case of the multi- } \\
\text { objective perspective }\end{array}$ & \\
\hline
\end{tabular}


TABLE 2. Corporate Governance Infused With Elements of Deliberative Democracy

\section{Implications for corporate governance}

Challenges of reflexive
and participative
governance (or, the
limitations of
deliberation)

Corporate governance needs to make sure firms can find a balance between:

- Participation and expertise

- Diversity and consensus

- Polycentricity and centralization

Ways to overcome the challenges:

Relying on various modes of participation

Relationship to responsible innovation
Building capacity for reflexivity

Corporate governance opens up for different Expertise allows for idea generation; degrees of stakeholder participation broad-based stakeholder inclusion allows for idea implementation

Corporate governance creates individual and structural conditions for reflexivity by including individuals with various perspectives and provides arenas for open discourse
Allows managers to draw on the potential for deliberation to deliberate with stakeholders about the goals (effectiveness), means (efficiency) and social acceptance (legitimacy) of innovation 
TABLE 3. Enabling Reflexivity and Participation in Corporate Governance

\begin{tabular}{|c|c|c|c|}
\hline $\begin{array}{l}\text { Innovative } \\
\text { corporate } \\
\text { governance aspects }\end{array}$ & $\begin{array}{l}\text { Future research could investigate what happens } \\
\text { when corporate governance ... }\end{array}$ & $\begin{array}{l}\text { Why we expect that this relates to reflexivity and } \\
\text { participation: }\end{array}$ & $\begin{array}{l}\text { Why we consider this conducive to responsible } \\
\text { innovation: }\end{array}$ \\
\hline Ownership structure & $\begin{array}{l}\text { Makes shareholding with long-term focus mandatory } \\
\text { Ensures that a percentage of shares is held by socially } \\
\text { responsible investors }\end{array}$ & $\begin{array}{l}\text { Increases the reflexivity of owners because they } \\
\text { need to consider long-term development } \\
\text { Ensures participation of shareholders with an interest } \\
\text { in sustainable development }\end{array}$ & $\begin{array}{l}\text { Shareholders can help to determine the focus on the } \\
\text { goals of responsible innovation }\end{array}$ \\
\hline $\begin{array}{l}\text { Accountability of } \\
\text { management }\end{array}$ & $\begin{array}{l}\text { Creates accountability toward society through } \\
\text { integrated reporting } \\
\text { Provides incentives for managers to contribute to } \\
\text { triple-bottom-line performance }\end{array}$ & $\begin{array}{l}\text { Encourages dialogue with external stakeholders who } \\
\text { assess the reports } \\
\text { Creates possibilities for reflection by considering } \\
\text { multiple performance objectives }\end{array}$ & $\begin{array}{l}\text { Provides necessary reflection on the goals } \\
\text { (effectiveness) and means (efficiency) of the firm's } \\
\text { innovation strategy }\end{array}$ \\
\hline Legal statute & $\begin{array}{l}\text { Adopts legal statutes that are emerging in several } \\
\text { countries and ties the corporation to a social purpose }\end{array}$ & $\begin{array}{l}\text { Increases managerial reflexivity about the } \\
\text { corporation's purpose and the goals of its innovation } \\
\text { processes. }\end{array}$ & $\begin{array}{l}\text { Legally obliges managers to dedicate resources to } \\
\text { foster the corporation's social purpose and thus to } \\
\text { pursue innovations that foster sustainable } \\
\text { development }\end{array}$ \\
\hline $\begin{array}{l}\text { Stakeholder } \\
\text { participation }\end{array}$ & $\begin{array}{l}\text { Includes expert stakeholders in the composition of the } \\
\text { board of directors or employs a stakeholder advisory } \\
\text { panel }\end{array}$ & $\begin{array}{l}\text { Allows for direct participation of stakeholders and } \\
\text { increases reflexivity through different voices }\end{array}$ & $\begin{array}{l}\text { Provides expertise that helps to reflect on the goals } \\
\text { (effectiveness) and means (efficiency) of the firm's } \\
\text { innovation strategy and can contribute to innovative } \\
\text { ideas }\end{array}$ \\
\hline & $\begin{array}{l}\text { Engages in broader discourse with all stakeholders } \\
\text { before the introduction of new products and processes }\end{array}$ & $\begin{array}{l}\text { Ensures broad-based participation and reflexivity to } \\
\text { secure social acceptance }\end{array}$ & $\begin{array}{l}\text { Secures social acceptance (legitimacy) of innovation } \\
\text { as the voices of those who are potentially affected } \\
\text { are heard }\end{array}$ \\
\hline $\begin{array}{l}\text { Modes of } \\
\text { decision making }\end{array}$ & $\begin{array}{l}\text { Bases decision making on open discourse aimed at } \\
\text { consensus among stakeholders when making decisions } \\
\text { about investing in } R \& D \text { and innovation }\end{array}$ & $\begin{array}{l}\text { Increases participation through various forms of } \\
\text { involvement of stakeholders in the decision-making } \\
\text { process }\end{array}$ & $\begin{array}{l}\text { Secures social acceptance (legitimacy) of innovation } \\
\text { as everyone supports the decision }\end{array}$ \\
\hline Resource allocation & $\begin{array}{l}\text { Provides (financial) resources for supporting new } \\
\text { social ventures within the corporation and in } \\
\text { collaboration with external partners }\end{array}$ & $\begin{array}{l}\text { Encourages bottom-up participation of employees in } \\
\text { responsible innovation processes and facilitates } \\
\text { exchanges with entrepreneurial ventures }\end{array}$ & $\begin{array}{l}\text { Allows for polycentric emergence of responsible } \\
\text { innovation within an organization }\end{array}$ \\
\hline
\end{tabular}


FIGURE 1. The Framework of Responsible Innovation

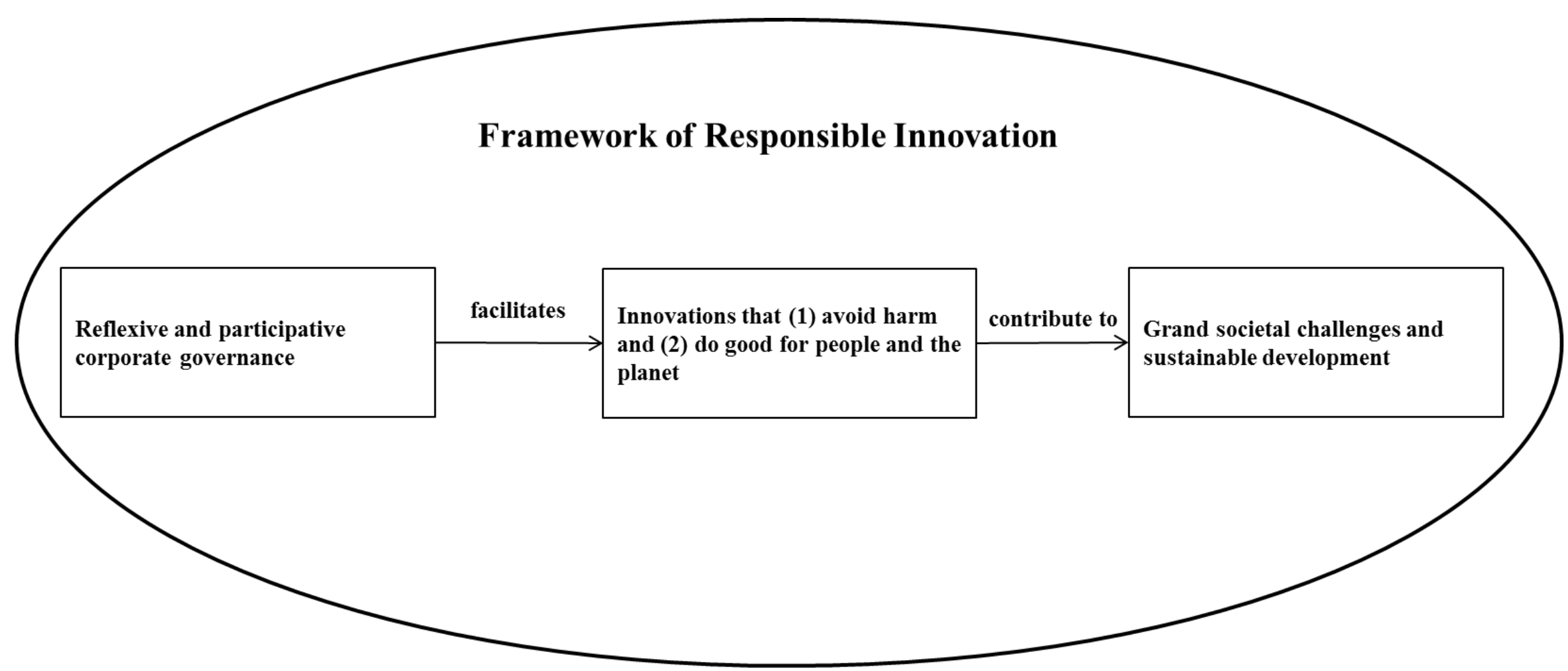




\section{BIOGRAPHIES}

Andreas Georg Scherer (andreas.scherer@uzh.ch) is a professor of business administration at the University of Zurich in Switzerland. He received his degrees at the University of Erlangen-Nuremberg in Germany. His research interests are in business ethics, corporate social responsibility, and organization theory. He has published nine books and more than 50 refereed papers in management and business ethics journals.

Christian Voegtlin (cvogtlin@audencia.com) is a professor of managerial responsibility at Audencia Business School in Nantes, France. He received his Ph.D. in business administration from the University of Zurich. His research interests are in responsible leadership and innovation, business ethics, and corporate social responsibility. He has published several articles on these topics. 